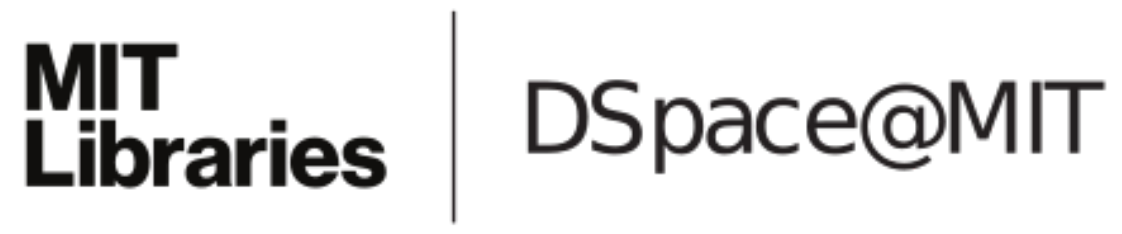

\author{
MIT Open Access Articles
}

Affinity Purification of Protein Complexes in C. elegans

The MIT Faculty has made this article openly available. Please share how this access benefits you. Your story matters.

Citation: Zanin, Esther et al. "Affinity Purification of Protein Complexes in C. Elegans." Methods in Cell Biology 106 (2011): 289-322 @ 2011 Elsevier Inc

As Published: http://dx.doi.org/10.1016/B978-0-12-544172-8.00011-6

Publisher: Elsevier

Persistent URL: http://hdl.handle.net/1721.1/116336

Version: Author's final manuscript: final author's manuscript post peer review, without publisher's formatting or copy editing

Terms of use: Creative Commons Attribution-NonCommercial-NoDerivs License 
Published in final edited form as:

Methods Cell Biol. 2011 ; 106: 289-322. doi:10.1016/B978-0-12-544172-8.00011-6.

\title{
Affinity Purification of Protein Complexes in C. elegans
}

\author{
Esther Zanin ${ }^{\star}$, Julien Dumont ${ }^{\dagger}$, Reto Gassmann ${ }^{*}$, Iain Cheeseman $\S$, Paul Maddox ${ }^{\ddagger}$, Shirin \\ Bahmanyar", Ana Carvalho*, Sherry Niessen", John R. Yates III", Karen Oegema*, and \\ Arshad Desai \\ *Ludwig Institute for Cancer Research and Department of Cellular \& Molecular Medicine, \\ University of California San Diego, La Jolla, California, USA \\ †Institut Curie-UMR144, Paris, France \\ FInstitute for Research in Immunology and Cancer, Department of Pathology and Cell Biology, \\ University of Montreal, Montreal, Quebec, Canada \\ \$Whitehead Institute for Biomedical Research, MIT, Cambridge, MA, USA \\ IThe Skaggs Institute for Chemical Biology and Department of Chemical Physiology, The Center \\ for Physiological Proteomics, The Scripps Research Institute, La Jolla, California, USA
}

\begin{abstract}
C. elegans is a powerful metazoan model system to address fundamental questions in cell and developmental biology. Research in C. elegans has traditionally focused on genetic, physiological, and cell biological approaches. However, C. elegans is also a facile system for biochemistry: worms are easy to grow in large quantities, the functionality of tagged fusion proteins can be assessed using mutants or RNAi, and the relevance of putative interaction partners can be rapidly tested in vivo. Combining biochemistry with function-based genetic and RNA interference screens can rapidly accelerate the delineation of protein networks and pathways in diverse contexts. In this chapter, we focus on two strategies to identify protein-protein interactions: single-step immunoprecipitation and tandem affinity purification. We describe methods for growth of worms in large-scale liquid culture, preparation of worm and embryo extracts, immunoprecipitation, and tandem affinity purification. In addition, we describe methods to test specificity of antibodies, strategies for optimizing starting material, and approaches to distinguish specific from nonspecific interactions.
\end{abstract}

\section{Introduction}

Caenorhabditis elegans is widely recognized as a powerful model system for cell and developmental biology. The landmark work that described the cell lineage from embryo to adult provided the foundation to study cell biology in the context of development in $C$. elegans (Sulston et al., 1983). Research in C. elegans has traditionally emphasized genetic and physiological approaches to elucidate gene function. Classical epistasis analysis groups genes isolated by mutagenesis screens into distinct pathways (Huang and Sternberg, 2006). In the past decade, genome-wide RNAi screens have greatly accelerated the annotation of gene functions (Fernandez et al., 2005; Kamath et al., 2003; Piano et al., 2000, 2002; Sonnichsen et al., 2005). Until recently, biochemical studies have lagged behind, primarily due to the historical trajectory of C. elegans research. However, C. elegans is a facile system for biochemical approaches as it is straightforward to grow worms in large quantities, assess the functionality of tagged fusion proteins using mutants or RNAi, and test the relevance of any identified interacting protein rapidly through in silico analysis and in vivo methods (Audhya and Desai, 2008; Moresco et al., 2010). 
In this chapter, we focus on methods in C. elegans for isolating protein complexes and identifying new interacting proteins using mass spectrometry. In addition, we describe cloning vectors that are useful for protein tagging and methods to assess antibody specificity. To identify new interaction proteins we employ two major strategies. In the first strategy, the target protein is purified using single-step immunoprecipitation (IP) with an affinity purified polyclonal antibody and the entire immunoprecipitate is subjected to mass spectrometric analysis. Immunoprecipitation of the endogenous protein has several advantages: protein expression is controlled by the endogenous promoter and protein function is not altered by addition of a tag. The drawback of this approach is that a large number of proteins are detected using current highly sensitive mass spectrometry methods. This poses a challenge for discriminating between relevant and non-specific interactions and therefore the significance of co-purified proteins needs to be carefully evaluated in followup work. A potential additional drawback is that binding of the primary antibody may block association with a subset of interacting components. In the second strategy, we use tandem affinity purification (TAP) to isolate high affinity complexes (Rigaut et al., 1999). Two sequential affinity purification steps significantly reduce background and lead to clean isolation of protein complexes. Two potential drawbacks of this approach are that the tag has the potential to alter protein function and that the stringency of the two-step purification procedure may cause loss of low affinity interacting proteins. As either strategy has drawbacks, whenever possible we conduct both in parallel. Such a dual approach was critical in defining the protein network that constitutes the core microtubule-binding site of the chromosome during cell division (Cheeseman et al., 2004; Desai et al., 2003).

Below we discuss first the tools necessary for biochemical analysis of a protein of interest followed by detailed methods for large-scale worm culture, extract preparation, and protein complex isolation (Fig. 1). We additionally profile methods to assess specificity of antibodies and optimize starting material for complex isolations.

\section{Generating Tools for Biochemistry}

\section{A. Generating a Polyclonal Antibody}

We highly recommend that an affinity-purified antibody be generated to every protein of interest. An antibody that recognizes its target with high specificity is an invaluable reagent, and in most cases will be suitable for immunoprecipitation, localization studies, and immunoblotting. Ideally, two independent antibodies should be generated against nonoverlapping epitopes. We have had good success with soluble fusion protein fragments of 100-200 amino acids expressed in bacteria, purified, and sent to a commercial vendor for antisera production (almost always in rabbits). The antibody is affinity purified from the antisera using columns with immobilized antigen that lack the fusion tag used for the initial antigen purification. Alternatively, antibodies against the tag can be first depleted from the antisera prior to affinity purification. Peptide antibodies can also be produced but, in our experience, have significantly lower rates of success than fusion protein antibodies. A newer option is DNA-based immunization, which does not require antigen purification for immunization but still requires purified protein for affinity purification of the antisera (Chowdhury, 2003).

The specificity of the affinity-purified antibody must be validated by immunoblot and immunofluorescence using wild-type and mutant backgrounds. If a mutant is not available, RNAi targeting the protein of interest should be performed. The most common crossreactivity we have observed in fusion protein injection-generated antibodies is to $E$. coli proteins that are present in both the injected antigen and in the antigen preparations used for affinity purification. Because worms eat $E$. coli, bacterial protein epitopes are difficult to eliminate. If the protein of interest is present in embryos, the use of embryo isolated by 
bleaching avoids this problem as these do not have bacterial epitopes. Contaminating antibodies to bacterial proteins can be depleted using immobilized E. coli lysate (Thermoscientific Cat. \#44938) and also blocked by adding an unrelated fusion protein preparation that harbors similar contaminants. For both immunofluorescence and immunoblotting, we typically use $0.5-1 \mu \mathrm{g} / \mathrm{mL}$ affinity-purified antibody in the primary antibody incubation step. To deplete contaminating anti-bacterial protein antibodies, we incubate $500 \mu \mathrm{L}$ of $10 \mu \mathrm{g} / \mathrm{mL}$ affinity purified antibody (diluted in AbDil: PBS $+2 \%$ BSA + $0.1 \%$ Triton X-100 $+0.1 \%$ sodium azide) with $100 \mu \mathrm{L}$ of $E$. coli protein agarose for $1-2 \mathrm{~h}$ at room temperature. The supernatant is then mixed with $50 \mu \mathrm{g} / \mathrm{mL}$ final concentration of an unrelated fusion protein purified from bacteria (harboring the same tag as the antigen) and then used for immunoblotting. This procedure eliminates anti-bacterial protein antibody cross-reactivity even in highly sensitive chemiluminescent detection.

\section{B. Assessing Antibody Specificity by Immunoblotting after RNAi}

The following protocol describes how to prepare worm extract for immunoblot analysis to test antibody specificity. It is important to wash the worms thoroughly to remove bacteria. Worms can be washed for up to $2 \mathrm{~h}$ in M9 containing $0.1 \%$ Triton X-100 if bacterial contamination remains a problem. As noted above, a good way to prevent bacterial epitopes in the sample is to use embryonic extract. However, a tradeoff with using embryo extract is that RNAi has to be performed by feeding, which might be less penetrant than injection. Therefore, we routinely perform RNAi blots using worms and, if necessary, treat the primary antibody to remove/block antibodies to bacterial epitopes.

To determine RNAi efficiency, a serial dilution of extract prepared from wild-type worms should be analyzed on the same blot as the RNAi extract sample (Fig. 2). As a loading control, a primary antibody of a different species should be used - we typically use anti $\alpha$ tubulin antibody that was generated in mouse (DM1 A Sigma-Aldrich, Cat. \#T9026).

RNAi-mediated depletion of gene products has shown to be effective for a large number of genes, including essential genes (Green et al., 2011; Kamath et al., 2003; Sonnichsen et al., 2005). If reduction of the band detected by western blotting is not observed after RNAi this may be due to low RNAi efficacy or due to the antibody recognizing a non-specific band of similar molecular weight as the gene product of interest. In this case, alternate RNAi conditions (feeding, injection, soaking, temperature, and time) or, ideally, null mutants should be analyzed by western blotting to assess antibody specificity.

Before starting

Pipet $15 \mu \mathrm{L}$ water into two screw-cap tubes, mark the liquid level, and remove the water.

Put distilled water in sonicating water bath (Bransonic Ultrasonic Cleaner 3510) and turn heating to $80^{\circ} \mathrm{C}$ or to maximum. If the sonicating water bath does not have heating capability, boiling water should be added prior to use.

1. Transfer $30 \mathrm{RNAi}$ and 30 control worms into $0.5 \mathrm{~mL} \mathrm{M} 9$ in marked tubes. We typically use injection as a method for RNAi as it has the best penetrance for early embryonic depletions, but soaking or feeding can also be used.

2. Add $1 \mathrm{~mL} \mathrm{M9}$ and pellet at $200 \mathrm{~g}$ in a microcentrifuge. Carefully remove supernatant leaving the worms undisturbed.

3. Repeat step 2 two times.

4. After last wash, remove all liquid down to $15 \mu \mathrm{L}$ mark and add $15 \mu \mathrm{L} 2 \times$ Sample Buffer. 
5. Place in sonicating water bath at $80^{\circ} \mathrm{C}$. Sonicate on maximum setting for $15-20$ $\min$.

6. Microcentrifuge at $200 \mathrm{~g}$ and check that worms have dissolved (you should not see a pellet). If a significant pellet remains boil the samples at $95{ }^{\circ} \mathrm{C}$ in a heat block with intermittent vortexing.

7. Lightly centrifuge, mix by flicking, and load $\sim 10 \mu \mathrm{L} /$ lane for immunoblots (aim for one worm per microliter of final sample).

\section{Tandem Affinity Purification Tags}

Tandem Affinity Purification allows the isolation of protein complexes in high purity. A composite tag is fused to the protein of interest containing two different purification tags separated by a protease cleavage site (Fig. 3). The original TAP tag used a domain of protein A that binds to IgG and a calmodulin-binding peptide (CBP) separated by a highly specific tobacco etch virus (TEV) protease site (Rigaut et al., 1999). In C. elegans, a version of this approach that we have used with significant success is the localization and affinity purification (LAP) tag (Cheeseman and Desai, 2005). The LAP tag is a modification of the TAP tag that can be used to both affinity purify the fusion protein and study its in vivo localization dynamics. The LAP tag contains GFP (or mCherry) and S peptide (that binds $\mathrm{S}$ protein with high affinity) separated by a TEV cleavage site (Fig. 3A). The LAP-tag fusion protein is first purified using anti-GFP-coupled beads, released from the beads by TEV protease cleavage and further purified in a second step over S protein agarose. The LAP tag has been successfully used in several studies to isolate new protein complexes (Audhya $e t$ al., 2005; Cheeseman et al., 2004; Dammermann et al., 2009; Gassmann et al., 2008). When using this tag for analysis of protein complexes containing RNA, it should be kept in mind that the binding of $\mathrm{S}$ peptide to $\mathrm{S}$ protein reconstitutes an active ribonuclease.

Several LAP-tag containing vectors are available: pIC26 allows fusing the target protein at its N-terminus to the LAP tag using a SpeI restriction site (Fig. 3B-D) (Cheeseman et al., 2004). pIC26 contains pie- 1 regulatory sequences to express the LAP-tagged protein in the germline and embryo and can be integrated by ballistic bombardment of the strain DP38 using unc-119 as a transformation marker (see Section II.D.). pAA65 contains the same features as pIC26 but has mCherry instead of GFP as a fluorescent tag (Fig. 3B, D) (McNally et al., 2006). C. elegans LAP vectors were reduced in size by introducing a truncated version of unc-119 in TH314 and TH315 (Fig. 3D). However, incomplete rescue of the Unc phenotype makes the identification of transformants more challenging. The target gene can be inserted in these vectors at the 3' end of GFP by either Gateway cloning (TH315) or conventional cloning (TH314). To fuse the protein of interest at the C-terminus to the LAP tag either pAZ-GFPc (truncated unc-119) or pEZ-13 (full length unc-119) can be used (Fig. 3D). The LAP tag can easily be transferred into other vectors using the cassette present in pIC26.

Instead of fusing both tags to one protein, it is also possible to fuse them to different members of the same protein complex. Such a "split" TAP tag was used to isolate new binding partners of the integral membrane nicotinic acetylcholine receptor (nAChR) (Gottschalk et al., 2005). Additional epitopes have been implemented for tandem affinity purifications (Polanowska et al., 2004; Schaffer et al., 2010).

\section{Introduction of Transgenes for Expression of Tagged Proteins}

For somatic expression of transgenes, heritable and repetitive extrachromosomal arrays are often sufficient; for example, Gottschalk et al. used an array to express TAP-tagged nAChR subunits (Gottschalk et al., 2005). Injecting DNA in the $C$. elegans germline will generate 
extrachromosomal arrays (Mello and Fire, 1995; Mello et al., 1991). However, a transgene in an array is typically overexpressed in somatic cells and rapidly silenced in germ cells (Kelly and Fire, 1998; Seydoux and Strome, 1999). The variable degree of heritability of the arrays can also make it difficult to obtain sufficient material from large-scale cultures.

An alternative to arrays is ballistic bombardment where small transgene-coated gold particles are introduced into the worm tissue at high speed (Praitis et al., 2001).

Bombardments are performed in the DP38 strain that carries a mutation in the unc-119 gene. The DP38 strain is unable to move and does not transition to the dauer stage. A copy of the unc-119(+) gene is introduced in the same vector as the transgene and transformants are identified by wild-type movement and dauer formation. Ballistic bombardment yields lowcopy number integrations at random sites in the genome. Bombarded transgenes may not be expressed at the endogenous level nor at all relevant developmental stages. Another drawback of generating transgenic lines by ballistic bombardment is that the integration sites are different for each transgene making it difficult to compare wild-type and engineered mutants. Detailed procedure for ballistic bombardment is described in Green et al. (2008) and on the Seydoux laboratory website (http://www.bs.jhmi.edu/MBG/SeydouxLab/vectors/index.html).

A recent technique, MosSCI (Mos1 mediated Single Copy transgene Insertion) circumvents the problems associated with arrays and bombarded lines by directing the transgene at a fixed locus in the genome (Frokjaer-Jensen et al., 2008). Transformants are identified using the same strategy as for ballistic bombardment: the injected strain contains an unc-119(ed3) mutation that is rescued by introducing the wild-type unc-119(+) gene on the vector harboring the transgene. Description of the vectors and a detailed protocol for MosSCI can be found on the webpage of the Jorgensen laboratory that developed this method (http://sites.google.com/site/jorgensenmossci/Home).

\section{E. Validating the Functionality of the Transgene-Encoded Tagged Protein}

Before using the tagged protein for biochemical studies it is important to validate its functionality. The most straightforward test is whether the fusion protein can rescue a mutant phenotype. If a mutant is not available, functional tests can be conducted using RNAi. This requires that the endogenous messenger RNA is specifically targeted by a dsRNA. Re-encoding transgenes or using a different 3'UTR on the transgene are two strategies that have been used for this purpose (Audhya et al., 2005; Dammermann et al., 2008). A detailed description of how we re-encode transgenes was recently presented (Green et al., 2008).

\section{The Optimal Starting Material for Protein Purification}

For proteins that are widely expressed, adult worms are the most straightforward starting material to use since they are easily grown in large-scale using liquid culture. If the protein of interest is enriched in embryos, embryonic extracts can be made by bleaching adult hermaphrodites to isolate embryos. By carefully choosing the incubation temperature it is also possible to enrich the embryonic extract either for young ( $<50$ cells) or old embryos (>200 cells) (see Section III.I.). If the target protein is present only in specific cell types, one can try to enrich for these cell types by using conditional loss of function mutations. For example, by using a temperature-sensitive mutant that does not form a germline one can enrich for somatic cells (Beanan and Strome, 1992). We describe in Section III.I. a strategy that uses a temperature-sensitive meiotic arrest mutant to enrich for embryos in meiosis I. While flow cytometry sorting methods have been developed to isolate specific cell types for expression and small RNA analysis, the amounts enriched are not yet sufficient for biochemical methods (Cinar et al., 2005; Colosimo et al., 2004; Fernandez et al., 2010; 
Zhang et al., 2002). Future miniaturization of protein isolation methods is likely to enable proteomic characterization of individual cell types sorted by flow cytometry.

\section{A. Growing Worms in Large-Scale Liquid Culture}

Worms are relatively straightforward to grow in biochemical quantities using liquid cultures. Growing worms on egg plates is an alternative approach and a detailed protocol for their use is described by Mains \& McGhee (Hope, 1999). The following protocols describe growing worms in large-scale liquid culture to obtain sufficient amount of either adult worms or embryos to perform immunoprecipitations or TAPs for mass spectrometry. The required buffers, solutions, and equipment are listed in Sections X and XI.

The standard procedure for liquid cultures is outlined in Fig. 4. First, adult worms are grown on OP-50 seeded $100 \mathrm{~mm}$ NGM agarose plates to obtain starved larvae that are used to initiate an unsynchronized liquid starter culture. Adults are harvested, embryos isolated by bleaching and hatched as L1s in the absence of food. Synchronized L1s are used to set up the second round of liquid culture and worms or embryos are harvested for extract generation. Worms and embryos can be stored at $-80{ }^{\circ} \mathrm{C}$ until sufficient amounts for immunoprecipitation are obtained. $500 \mathrm{~mL}$ liquid worm culture yields about $7 \mathrm{~g}$ of worms and $0.7 \mathrm{~g}$ of embryos.

Growth of worms in liquid culture should be carefully and continuously monitored. It is important to determine under a dissecting microscope the age of the worms, whether they have sufficient amounts of food, and if contamination is present. Cultures must be handled under sterile conditions, preferably in a dedicated laminar flow hood to avoid contamination. Growth temperature can be adjusted between $16{ }^{\circ} \mathrm{C}$ and $25^{\circ} \mathrm{C}$ and it is recommended to use a cooling shaker that reliably holds temperature.

\section{B. Unsynchronized Liquid Starter Culture}

Since contamination is a serious problem in liquid culture, we recommend starting with freshly axenized worms. These are then amplified on $100 \mathrm{~mm}$ NGM agarose plates by putting 15 cleaned worms onto each plate (Fig. 4). After incubating the plates for 4-5 days at $20^{\circ} \mathrm{C}$ the just starved larvae are used to start the unsynchronized liquid culture.

1. Day 1: Pipet $5 \mu \mathrm{L} 2 \mathrm{M} \mathrm{NaOH}$ and $5 \mu \mathrm{L}$ of bleach at edge of bacteria on a $60 \mathrm{~mm}$ NGM agarose plate. Transfer 10 adult worms into $\mathrm{NaOH} / \mathrm{bleach}$ drop. Wait until L1 larvae hatch and transfer L1 larvae onto new plates and grow until they are adults.

2. Day 5: Seed $100 \mathrm{~mm}$ NGM agarose plates with 15 cleaned adults. You will need 78 plates per $500 \mathrm{~mL}$ of liquid culture. Incubate plates at $20^{\circ} \mathrm{C}$ for $4-5$ days until worms are just starved.

3. Day 8: Start a $50 \mathrm{~mL}$ overnight of OP-50-1 in $\mathrm{LB}+50 \mu \mathrm{g} / \mathrm{mL}$ streptomycin. OP-50-1 is a streptomycin resistant $E$. coli strain.

4. Day 9: Start $1.5 \mathrm{~L}$ culture of OP-50-1 in LB $+50 \mu \mathrm{g} / \mathrm{mL}$ streptomycin. You will need $1.5 \mathrm{~L}$ of bacterial culture as food for $500 \mathrm{~mL}$ of $C$. elegans culture.

5. Day 10:

- Harvest bacterial culture at $4200 \mathrm{rpm}$ for $15 \mathrm{~min}$ in sterile $1 \mathrm{~L}$ centrifuge bottles. Pour off LB. Bacterial food can be stored in $50 \mathrm{~mL}$ conicals at 4 ${ }^{\circ} \mathrm{C}$ for several weeks.

- Make $500 \mathrm{~mL}$ Complete S Basal. 
- Resuspend bacterial pellet in $20 \mathrm{~mL}$ Complete $\mathrm{S}$ Basal and transfer into a sterile $2.8 \mathrm{~L}$ wide bottom Fernbach flask with $500 \mathrm{~mL}$ Complete S Basal.

- $\quad$ Rinse 7-8 plates of just starved larvae with $10 \mathrm{~mL}$ of sterile M9. To collect as many worms as possible from plates repeat wash with $5 \mathrm{~mL}$ of M9. Check plates to make sure most worms were washed off. Collect in a $50 \mathrm{~mL}$ conical.

- Pellet worms at $600 \mathrm{~g}$ in centrifuge for $3 \mathrm{~min}$ with slow deceleration. Remove supernatant with a sterile pipet and discard. Resuspend worms in $5 \mathrm{~mL}$ of fresh M9 and add to flask containing the Complete $\mathrm{S}$ Basal with bacteria. Shake the inoculated culture at $20{ }^{\circ} \mathrm{C}$ at $200-230 \mathrm{rpm}$. Adjust growth time by varying temperature between $16{ }^{\circ} \mathrm{C}$ and $25^{\circ} \mathrm{C}$.

6. Days 11-13: Growth of the culture should be carefully followed (see Section III C.) and worms harvested when majority are adults. The culture will take about 3-3.5 days depending on age of worms on starter plates and the desired state of the final culture.

Note: The bacterial food for liquid culture can be obtained from fermentor facilities. However, we have had contamination as well as growth problems with externally supplied food and, consequently, prefer growing up our own bacterial cultures.

\section{Monitoring Worm Cultures}

Worm liquid cultures should be monitored under a dissecting microscope once a day. This allows assessment of the developmental stage and health of the worms, ensures that worms have enough food, and confirms that there is no significant contamination.

1. In a laminar flow hood transfer $1 \mathrm{~mL}$ of the culture with a sterile pipet into $1.5 \mathrm{~mL}$ microcentrifuge tubes.

2. Spin in microcentrifuge $600 \mathrm{~g}$ for $3 \mathrm{~min}$.

3. Carefully pipet $\sim 20 \mu \mathrm{L}$ worm slurry using a cut-off tip onto a glass slide. Place cover slip on top and look at the worms under dissecting microscope.

\section{Harvesting Worms from Liquid Cultures}

Worms are harvested by settling under gravity and cleaned by flotation on a sucrose cushion, which separates healthy worms from bacteria and debris (Fig. 4). The sucrose floated worms are washed and used to isolate embryos.

1. When the majority of worms in the culture have 10-15 embryos, transfer the cultures into $500 \mathrm{~mL}$ graduated cylinders. Settle worms in ice water bath for $1 \mathrm{~h}$.

2. Aspirate off media using a sterile $5 \mathrm{~mL}$ pipet and transfer slurry (brown film at bottom) to two $50 \mathrm{~mL}$ conicals per L culture.

3. Pellet in centrifuge at $600 \mathrm{~g}$ for $3 \mathrm{~min}$ with slow deceleration.

4. Aspirate off supernatant, collect worms into $50 \mathrm{~mL}$ conical, and add cold $\mathrm{M} 9$.

5. Pellet in centrifuge at $600 \mathrm{~g}$ for $3 \mathrm{~min}$ and aspirate off supernatant.

6. Resuspend pelleted worms by adding cold $\mathrm{M} 9$ to the $25 \mathrm{~mL}$ mark. To this add 25 $\mathrm{mL}$ cold $60 \%(\mathrm{w} / \mathrm{v})$ sucrose. Mix and centrifuge immediately at $1500 \mathrm{~g}$ for $5 \mathrm{~min}$.

7. After the spin, adult worms will forma layer at the top of the tube. Remove adults down to the $35 \mathrm{~mL}$ mark with $5 \mathrm{~mL}$ pipet and transfer to a new conical. 
8. Wash worms by adding cold M9 to $50 \mathrm{~mL}$ mark. Pellet the worms at $600 \mathrm{~g}$ for 3 min and carefully remove supernatant.

Note: It is important to work rapidly during the sucrose flotation step. Do not leave the worms for too long in sucrose and wash them out of sucrose rapidly after collection from the top of the cushion.

\section{E. Isolation of Embryos and Synchronization as Starved L1 Larvae}

The washed worms are bleached to isolate embryos (Fig. 4). Good bleaching efficiency depends on small volumes (maximum $5 \mathrm{~mL}$ worm pellet per $50 \mathrm{~mL}$ conical) and freshness of bleach. Bleaching should be followed by eye under a dissecting microscope. Bleaching sterilizes the culture; after bleaching, sterile technique becomes critical again so that no contaminants are introduced into the material that will be used to inoculate the synchronized liquid culture.

1. To worm pellet add $25 \mathrm{~mL} 0.1 \mathrm{M} \mathrm{NaCl}$ and mix by pipeting up and down twice. Settle worms on ice for $5 \mathrm{~min}$.

2. Aspirate off supernatant including worms that have not settled to the bottom and add $0.1 \mathrm{M} \mathrm{NaCl}$ up to a volume of $30 \mathrm{~mL}$.

3. Mix $5 \mathrm{~mL} 5 \mathrm{~N} \mathrm{NaOH}$ with $10 \mathrm{~mL}$ bleach in conical. Immediately add $\mathrm{NaOH} / \mathrm{bleach}$ mix to $30 \mathrm{~mL}$ worm suspension.

4. Vortex at maximum speed for $5 \mathrm{~s}$ and stand tube at RT for $2 \mathrm{~min}$. Repeat four times for a total bleaching time of 7-9 min. Follow bleaching by examining samples on a glass slide under a dissecting microscope. Stop bleaching when only embryos remain. The color of the bleach mixture will change to a burnt orange as worms are dissolved.

5. Immediately centrifuge at $800 \mathrm{~g}$ for $1 \mathrm{~min}$ at $4{ }^{\circ} \mathrm{C}$. Aspirate off supernatant.

6. Add sterile water to a total volume of $50 \mathrm{~mL}$, mix by inverting the tube, and centrifuge at $800 \mathrm{~g}$ for $2 \mathrm{~min}$.

7. Repeat step 6. Washed embryos from synchronized liquid culture can be frozen for immunoprecipitation as described in Section III.H.

8. Add $35 \mathrm{~mL}$ M9 and transfer to a $50 \mathrm{~mL}$ flask. Rinse the conical with an extra 10 $\mathrm{mL}$ of sterile M9 and add to flask. Shake at $20^{\circ} \mathrm{C}$ until embryos hatch and are starved L1 larvae ( 18-20 h).

\section{F. Seeding Synchronized Cultures Using Starved L1 Larvae}

Starved L1 larvae from $500 \mathrm{~mL}$ starter flask can be expanded to inoculate up to six synchronized liquid cultures.

1. 2 Days before: Start $300 \mathrm{~mL}$ culture of $\mathrm{OP}-50-1 \mathrm{in} \mathrm{LB}+50 \mu \mathrm{g} / \mathrm{mL}$ streptomycin.

2. Day before: Start six $1.5 \mathrm{~L}$ cultures of OP-50-1 in LB $+50 \mu \mathrm{g} / \mathrm{mL}$ streptomycin.

3. Harvest bacterial cultures at $4200 \mathrm{rpm}$ for $15 \mathrm{~min}$ in sterile $1 \mathrm{~L}$ centrifuge bottles. Pour off LB.

4. Make $3 \mathrm{~L}$ Complete $\mathrm{S}$ Basal and distribute into six $2.8 \mathrm{~L}$ Fernbach flasks.

5. Resuspend bacterial pellet of each $1.5 \mathrm{~L}$ culture in $20 \mathrm{~mL}$ Complete $\mathrm{S}$ Basal and transfer into sterile $2.8 \mathrm{~L}$ Fernbach flask with $500 \mathrm{~mL}$ Complete S Basal. 
6. When flasks with bacterial food are ready, start processing starved L1s. In the hood, transfer $\mathrm{L} 1 \mathrm{~s}$ to a $50 \mathrm{~mL}$ conical. Chill on ice for 5-10 min.

7. Spin at $600 \mathrm{~g}$ for $3 \mathrm{~min}$. Carefully remove supernatant. Bring up to $50 \mathrm{~mL}$ with sterile cold M9.

8. Repeat step 7.

9. Add sterile $\mathrm{M} 9$ such that total volume is $\sim 5 \mathrm{~mL}$, transfer $\mathrm{L} 1 \mathrm{~s}$ to $15 \mathrm{~mL}$ conical, and pellet by spinning at $600 \mathrm{~g}$ for $2 \mathrm{~min}$. Immediately after the spin, use a pen to mark the volume of the pellet on the side of the tube. Estimate the volume of pellet by adding known volumes of water to a separate conical.

10. Resuspend $\mathrm{L} 1 \mathrm{~s}$ to total volume of $12 \mathrm{~mL}$ using sterile $\mathrm{M} 9$ and look at a sample under dissection microscope; estimate percentage of L1s relative to dead embryos/ worm parts/clumps.

11. Seed each flask with equivalent of $50 \mu \mathrm{L}$ pure $\mathrm{L} 1$ pellet (e.g., if pellet volume is 0.6 $\mathrm{mL}$ and $\% \mathrm{~L} 1$ in the resuspension is $70 \%$ then seed with $1.4 \mathrm{~mL}$ of the resuspended pellet). Avoid overseeding or cultures will starve.

12. Put flasks at $20^{\circ} \mathrm{C}$ at $230 \mathrm{rpm}$. Grow for $48 \mathrm{~h}$ while monitoring cultures under dissecting microscope.

\section{G. Freezing Adult Worms for Immunoprecipitation}

Once the liquid cultures are ready collect and wash worms as described in Section III.D. Wash worms by adding $50 \mathrm{~mL}$ cold $1 \times$ Lysis Buffer (with protease inhibitors). Remove Lysis Buffer until only a small amount remains. Freeze adult worms by dispensing from a pipette drop by drop in liquid nitrogen, which will form small beads (Fig. 4). Store at -80 ${ }^{\circ} \mathrm{C}$.

\section{H. Freezing Embryos for Immunoprecipitation}

Bleach adult worms as described in Section III.E. and continue after step 7.Wash embryo pellet with $50 \mathrm{~mL}$ cold $1 \times$ Lysis Buffer (with protease inhibitors). Freeze embryos by dispensing from a pipette drop by drop in liquid nitrogen. Store embryo beads at $-80{ }^{\circ} \mathrm{C}$.

\section{Enriching for Specific Age Embryos}

While precise synchronization of embryos is not possible, it is straightforward to enrich for old or young embryo populations by varying growth conditions and carefully monitoring worms in the culture under a dissecting microscope. Generate synchronized starved L1 larvae (see Section III.E.) and inoculate worm cultures (see Section III.F.). To obtain worms that just started embryo production, incubate the flask for $\sim 64 \mathrm{~h}$ at $17{ }^{\circ} \mathrm{C}$. Using these growth conditions worms typically contained up to five embryos, the majority of which have $<50$ cells (Fig. 5A). If several flasks of worm culture are grown simultaneously, it is necessary to monitor each flask separately, as the time at which embryo production begins may vary between flasks. It is also critical to avoid contamination, which may adversely affect synchronous growth of the worms. To obtain worms with mostly old embryos (>200 cells), cultures are incubated for $\sim 64 \mathrm{~h}$ at $19{ }^{\circ} \mathrm{C}$ (Fig. 5A). Embryos are frozen as described in Section III.H. To determine the age of the embryos, about $\sim 5 \mu \mathrm{L}$ of packed embryos are fixed in $1 \mathrm{~mL}$ of cold methanol for at least $30 \mathrm{~min}$, then incubated with $1 \mu \mathrm{g} / \mathrm{mL}$ Hoechst stain in PBS+0.1\% Triton X-100 for 10 min. After three washes with PBS+0.1\% Triton $\mathrm{X}-100$, embryos are suspended in $30 \mu \mathrm{L}$ PBS, and $5 \mu \mathrm{L}$ are mixed on a $18 \times 18 \mathrm{~mm}$ coverslip with $15 \mu \mathrm{L}$ of mounting medium. The coverslip is carefully placed on a slide, sealed with nail polish, and the number of nuclei per embryo is determined using a fluorescence microscope (Fig. 5A). 


\section{J. Enriching for Meiosis I Arrested Embryos}

Adult worms contain about 15 mitotically dividing embryos and at most two meiotic embryos because meiosis is completed $30 \mathrm{~min}$ after fertilization. To enrich for meiosis I metaphase, we used a mutation in a subunit of the anaphase-promoting complex (APC). We chose a temperature-sensitive allele ( $\mathrm{g} 48$ ) of $e m b-27$ (Cassada et al., 1981; Golden et al., 2000). At permissive temperature $\left(16^{\circ} \mathrm{C}\right) \mathrm{emb}-27(\mathrm{~g} 48)$ worms contain about 15 mitotically dividing embryos, similar to wild type. At the restrictive temperature $\left(24-25^{\circ} \mathrm{C}\right)$, emb-27(g48) embryos arrest at metaphase of meiosis I and worms accumulate meioticallyarrested fertilized embryos. Mutant worms are initially grown at $16^{\circ} \mathrm{C}$ as described in Section III. A.-E. It is important to keep the temperature at or below $16{ }^{\circ} \mathrm{C}$ to prevent metaphase arrest. Bleached larvae are used to inoculate a synchronized liquid culture (see Section III.F.) and are shifted to $24{ }^{\circ} \mathrm{C}$ when the majority of worms are at the $\mathrm{L} 4$ stage. The time point of temperature shifting has to be chosen carefully because an early shift causes larval arrest and a late shift will "contaminate" the extract with mitotic embryos. Worms are harvested when the majority contains 4-8 one-cell meiotic-arrested embryos and worm extract is prepared as described in Section V. Timing is once again critical since after 4-5 h the embryos overcome the meiotic arrest and start cycling endo-mitotically (DNA is replicated but cell division does not occur). The quality of the culture can be assayed by cutting 2-3 worms in a drop of L-15 blastomere culture medium (Edgar, 1995) containing 1 $\mu \mathrm{g} / \mathrm{mL}$ Hoechst 33342 , and analyzing the shape of the chromosomes. Metaphase I arrested embryos display six maternal chromosomes that have a typical oval shape (Fig. 5B). Endomitotic embryos contain decondensed chromosomes that have a fibrous-like appearance and tend to detach from the anterior cortex of the embryo (Fig. 5B).

The above two examples are specific to our research interests but related strategies can be used to enrich for cell types or stages of interest prior to protein complex isolations.

\section{Isolation of Nuclei from Embryos}

If the protein of interest is a nuclear protein or if DNA-protein interactions are being analyzed as in Chromatin Immunoprecipitation (ChIP) experiments, nuclei can be isolated from embryos prior to further analysis. Embryos are isolated by bleaching as described in Section III.E Steps 1-7; however it is important that embryos are not frozen prior to nuclei isolation. To isolate nuclei, the embryo eggshell is digested using chitinase (Fig. 6A). Dounce homogenization in hypotonic buffer liberates intact nuclei. A $100 \mathrm{~g}$ centrifugation removes large debris and a subsequent $2000 \mathrm{~g}$ centrifugation pellets the nuclei. A final centrifugation step over a sucrose cushion is used to separate the nuclei from membrane contaminants. Enrichment of nuclei can be easily followed by the emergence of the core histone bands on Coomassie-stained gels (Fig. 6B). Because the chitinase step is performed at room temperature, nuclei must be purified from freshly isolated embryos to avoid protein degradation. $1 \mathrm{~mL}$ of embryo pellet typically yields $\sim 100 \mu \mathrm{L}$ of nuclei.

1. Harvest embryos by bleaching as described in Section III.E. until step 7.

2. Add two embryo pellet volumes of Embryo Buffer and $250 \mu \mathrm{L}$ of chitinase stock solution per $\mathrm{mL}$ of embryo pellet.

3. Rotate at RT for $\sim 30 \mathrm{~min}$. Monitor eggshell integrity under dissecting microscope. Embryos without an eggshell will lose their oval shape and fall apart into clumps of cells.

4. Spin at $1000 \mathrm{~g}$ for $3 \mathrm{~min}$.

5. Wash pellet twice with $50 \mathrm{~mL}$ cold Embryo Buffer. All subsequent steps are performed on ice. 
6. After final wash, remove supernatant and resuspend embryos in $10 \mathrm{~mL} 0.5 \times$ Nuclei Buffer. Incubate for $15 \mathrm{~min}$ on ice to swell cells.

7. Add $10 \mathrm{~mL} 1 \times$ Nuclei Buffer (with $0.1 \%$ digitonin and protease inhibitors) and immediately dounce with $\sim 50$ strokes in a $15 \mathrm{~mL}$ Wheaton dounce homogenizer with a B pestle (tight fit).

8. Spin at $100 \mathrm{~g}$ for $3 \mathrm{~min}$. This centrifugation pellets large debris.

9. Remove supernatant that contains the nuclei and keep on ice.

10. Resuspend pellet in $10 \mathrm{~mL}$ Nuclei Buffer (with $0.1 \%$ digitonin and protease inhibitors) and dounce pellet as described in step 7.

11. Spin at $100 \mathrm{~g}$ for $3 \mathrm{~min}$ and combine two supernatants.

12. Spin at $2000 \mathrm{~g}$ for $15 \mathrm{~min}$ to pellet nuclei. Supernatant is cytoplasmic fraction.

13. Resuspend pellet in $500 \mu \mathrm{L}$ Nuclei Buffer (with $0.1 \%$ digitonin and protease inhibitors) and mix with $5 \mathrm{~mL} \mathrm{30 \%} \mathrm{(w/v)} \mathrm{sucrose} \mathrm{cushion} \mathrm{in} \mathrm{Nuclei} \mathrm{Buffer} \mathrm{with}$ $0.1 \%$ digitonin.

14. Centrifuge at $2000 \mathrm{~g}$ for $15 \mathrm{~min}$. The pellet will be enriched for nuclei.

15. Check integrity of the nuclei under a microscope after incubation with $1 \mu \mathrm{g} / \mathrm{mL}$ Hoechst stain (Fig. 6C).

\section{Preparing Worm and Embryonic Extract}

Extract can be prepared using whole worms harvested from liquid culture or from embryos isolated by bleaching. Lysis of worms and embryos is performed in an isotonic buffer. Subsequent to lysis, the salt concentration can be raised to $300 \mathrm{mM} \mathrm{KCl}$ to enhance stringency of protein complex isolation. Worms and embryos are lysed by grinding in liquid nitrogen followed by sonication (Fig. 7). Two consecutive centrifugations remove membranes and lipids and the supernatant is used for complex isolation. The lysis conditions described here are not well-suited for membrane-associated proteins. A protocol for isolating membrane proteins is described in Gottschalk et al. (2005).

1. Pre-cool a mortar and pestle by filling with liquid nitrogen for at least $5 \mathrm{~min}$.

2. Weigh out frozen adult/embryo beads. For one immunoprecipitation use $\sim 1 \mathrm{~g}$ of frozen worm/embryo beads. Grind frozen beads to a fine powder: initially break down worm/embryo beads by gentle tapping (try not to lose too many beads as they have a tendency to jump out of the mortar), then grind. Keep mortar cold by adding more liquid nitrogen as necessary and waiting for it to evaporate. For more than 40 $\mathrm{g}$ of worms, one can also use a warring blender cooled with liquid nitrogen. For embryo extracts, the freeze-grinding step may be skipped, as sonication is sufficient to release cytoplasmic contents.

3. Add an equal volume of $1.5 \times$ Lysis Buffer (with protease inhibitors) to each gram of adult/embryo beads. Keep $20 \mu \mathrm{L}$ sample for gel analysis.

4. Set up ice-water bath and sonicate with a tip sonicator (e.g., Branson Digital Sonifier). It is critical to prevent heating of the sample during sonication. For a Branson Digital Sonifier with a microtip use the following settings:

- $30 \%$ amplitude for 3 min total (15 s on; $45 \mathrm{~s}$ off - after each $1 \mathrm{~min}$ of sonication wait $\sim 2$ min to chill)

- $40 \%$ amplitude for $30 \mathrm{~s}$ (15 s on; $45 \mathrm{~s}$ off) Save $20 \mu \mathrm{L}$ sample. 
We recommend optimizing the sonication protocol by two methods:

Use a dissecting microscope to monitor worm/embryo lysis. At least 80-90\% of the worms/embryos must be lysed.

Use Bradford reagent or UV absorbance to directly monitor lysis. As cells lyse, the protein concentration and $\mathrm{A}_{260}$ absorbance (due to nucleic acid release) will increase. A test sonication should be performed to define conditions at which one or both of these values begin to plateau.

5. Transfer crude extract to TLA 100.3 tube and spin at $20,000 \mathrm{~g}$ for $10 \mathrm{~min}$ at $2{ }^{\circ} \mathrm{C}$, with medium deceleration. Save $20 \mu \mathrm{L}$ sample.

6. Transfer supernatant to new tube and pellet at $100,000 \mathrm{~g}$ for $20 \mathrm{~min}$ at $2{ }^{\circ} \mathrm{C}$. Try to avoid lipid and re-pellet if too cloudy. Save $20 \mu \mathrm{L}$ sample.

7. Transfer supernatant to a tube on ice. This extract will be used for purifications. All samples and the extract may be frozen in liquid nitrogen and stored at $-80{ }^{\circ} \mathrm{C}$ until further use.

8. Use Bradford reagent to measure protein concentration in extract.

\section{Single-step Immunoprecipitation}

Immunoprecipitation using specific antibodies is a powerful method for analyzing proteinprotein interactions and identifying protein complexes. Single-step purification using polyclonal antibodies followed by mass spectrometry on the entire eluate commonly indentifies several hundred to a thousand proteins making it challenging to distinguish between signal and noise. Background can arise from general non-specific binding to beads, to constant regions of antibody chains, and to partially denatured antibodies. Background can also be specific to individual affinity-purified antibodies - consequently a random IgG control cannot be used to discriminate between true signal and noise. We recommend using as a control a polyclonal rabbit antibody raised against GST (glutathione S-transferase) that is affinity-purified using the same procedures used for the antibody to the target protein. In addition, whenever possible, we recommend parallel immunoprecipitations with either two antibodies to the same protein (preferable with non-overlapping epitopes) or one antibody and one tagged fusion protein. Purification from a mutant strain is an ideal negative control but is not feasible if the mutation is lethal. If a tagged protein is immunoprecipitated, an untagged strain can be used as a negative control.

The following two examples illustrate how redundant purification strategies and suitable negative controls helped pinpoint bona fide complex members. Polyclonal rabbit antibodies to two essential chromosome segregation proteins, KNL-1 and KNL-3, identified in an RNAi screen, were used to purify complexes containing these proteins (Cheeseman et al., 2004; Desai et al., 2003). Each protein was present in the other immunoprecipitation, allowing cross-referencing of the two immunoprecipitations to identify 11 proteins in common (Fig. 8) (in total the two immunoprecipitations identified over 130 proteins). MIS-12 and KBP-1, two of the newly discovered proteins that were in the common set were LAP tagged and tandem affinity purified revealing a 10-protein complex containing both KNL-1 and KNL-3 (Fig. 8). Functional validation confirmed that all of the proteins that copurified were involved in chromosome segregation.

In a second example, novel interaction partners of $C$. elegans Dicer (DCR-1), a RNA endoribonuclease that is required in mammalian cells for small RNA generation, were identified by single-step purification (Duchaine et al., 2006). Two single-step DCR-1 immunoprecipitations were performed: one using adult worms with a polyclonal anti-DCR-1 antibody and one using embryos that express HA-tagged DCR-1. Negative control 
purifications were performed in a $d c r-1$ mutant strain, an untagged wild-type strain and with unrelated antibodies. Co-purified proteins were considered high confidence interactors if they were reproducibly identified in at least two independent purifications and not present in the negative control purifications. Twenty high confidence interactors were analyzed further with biological assays. Twelve of the 20 interactors could be linked to DCR-1 activities or its small-RNA products.

These two examples illustrate the importance of experimental design that incorporates redundancy at the outset. The need for employing such strategies has been magnified by the significant technical advances in protein mass spectrometry - currently, one-step immunoprecipitations with an affinity-purified antibody frequently yield between 100 and 1000 distinct proteins in the immunoprecipitate. We note that existing datasets can provide computational tools for filtering the output of mass spectrometric analysis. For example, over the years we have conducted a large number of protein isolation and mass spectrometry experiments in C. elegans embryos. The targets for this analysis span a number of cellular processes. This cumulative dataset helps identify potentially interesting candidates from a new purification experiment as opposed to frequently observed co-purifying "sticky" proteins. New label free quantitative mass spectrometry methods can also be employed to help discriminate true signal from noise (Hubner et al., 2010).

We note that, prior to mass spectrometry, it is important to assess the solubility of the protein target and the efficiency of the immunoprecipitation using immunoblotting. For this purpose, samples of the crude extract, low-speed supernatant, high-speed supernatant, the supernatant after incubation with antibody beads, and the immunoprecipitate are important to prepare and store, keeping track of the volumes at each step. Such an effort can quickly identify potential confounding problems (e.g., low solubility or poor immunoprecipitation efficiency) and guide approaches to overcome them.

Below, we describe how to covalently couple the affinity-purified antibody to protein A beads, use the antibody-coupled beads for immunoprecipitation, and elute bound proteins from the beads for analysis by mass spectrometry, silver staining and immunoblotting (Fig. $7)$.

\section{A. Covalent Coupling of Antibodies to Protein A Beads}

Immunoprecipitation and tandem affinity purification both start with coupling the antibody to Protein A resin. For antibodies generated in species with weak affinity to protein A, protein $\mathrm{G}$ resin should be used. Coupling greatly reduces antibody leaching during elutions. The tradeoff is a reduction in antibody efficacy because coupling is performed using a bifunctional amine crosslinker that to a variable extent will react with the antigen-binding site. The use of the crosslinker dimethylpimelidimate (DMP) for coupling is based on the protocol described in Harlow and Lane (Harlow et al., 1999).

Amounts indicated are for one tube of coupled beads

- For one TAP purification prepare four tubes.

- For one-step immunoprecipitation used for mass spectrometry prepare one tube.

- Volume of Protein A beads indicated is for settled beads, material received from Biorad is a 1:1 slurry.

1. Equilibrate $\sim 120 \mu \mathrm{L}$ Affi-Prep Protein A beads into PBST(PBS $+0.1 \%$ Tween-20) by washing the beads three to four times with $1 \mathrm{~mL}$ PBST. This should give about $60 \mu \mathrm{L}$ of packed beads. Wash beads by gentle inversion. Briefly pellet them using a 
pulse in a microcentrifuge ( $30 \mathrm{~s}$ at $3000 \mathrm{~g}$ ) and remove supernatant avoiding bead pellet.

2. Resuspend beads in $500 \mu \mathrm{L}$ PBST and add $10-50 \mu \mathrm{g}$ of affinity-purified antibody. Mix for $45 \mathrm{~min}-1 \mathrm{~h}$ at RT on a rotor to allow antibodies to bind to resin.

3. Wash beads three times with $1 \mathrm{~mL}$ PBST as described in step 1 .

4. Wash beads three times with $1 \mathrm{~mL} 0.2 \mathrm{M}$ sodium borate ( $\mathrm{pH}$ 9.0) (dilute from a stock of $1 \mathrm{M}$ sodium borate ( $\mathrm{pH} 9.0)$ ). After the final wash, add $900 \mu \mathrm{L}$ of the 0.2 M sodium borate ( $\mathrm{pH} 9.0$ ) to bring the final volume to $\sim 1 \mathrm{~mL}$.

5. To initiate coupling add $100 \mu \mathrm{L}$ of $220 \mathrm{mM}$ DMP. Rotate tubes gently at RT for 30 min.

6. To make DMP: Let bottle sit tightly closed at RT for $20 \mathrm{~min}$ before opening. Weigh out DMP and leave dry until just before use. Resuspend in appropriate volume of $0.2 \mathrm{M}$ sodium borate ( $\mathrm{pH}$ 9.0) and add immediately to the bead suspension (e.g., for $34 \mathrm{mg}$ DMP add $596 \mu \mathrm{L}$ sodium borate).

7. After incubation with DMP, wash beads two times with $1 \mathrm{~mL} 0.2 \mathrm{M}$ ethanolamine, $0.2 \mathrm{M} \mathrm{NaCl}(\mathrm{pH} 8.5)$ to inactivate the residual crosslinker. Resuspend in $1 \mathrm{~mL}$ of the same buffer and rotate for $1 \mathrm{~h}$ at RT. Resuspend beads in $500 \mu \mathrm{L}$ of the same buffer. Leave the beads in $0.2 \mathrm{M}$ ethanolamine, $0.2 \mathrm{M} \mathrm{NaCl}(\mathrm{pH} 8.5)$ at $4{ }^{\circ} \mathrm{C}$ until use. Beads are stable at $4{ }^{\circ} \mathrm{C}$ for at least one month.

\section{B. Immunoprecipitation}

To prevent proteolysis it is important to keep the beads on ice and cool all buffers and tubes before use. Using higher stringency conditions $(300 \mathrm{mM} \mathrm{KCl})$ reduces background although there is also an increased likelihood of losing meaningful low affinity interactions.

1. Pre-elute $100 \mu \mathrm{L}$ of antibody-coupled beads three times with $1 \mathrm{~mL}$ of $100 \mathrm{mM}$ glycine ( $\mathrm{pH}$ 2.6) to remove antibody that is not covalently coupled to the beads. Do not leave beads for a long time in glycine or the antibody will denature.

2. Wash beads three times with $1 \mathrm{~mL}$ cold Lysis Buffer (with $0.5 \mathrm{mM}$ DTT) to neutralize glycine and prepare the beads for immunoprecipitation.

3. Mix beads with $900 \mu \mathrm{L}$ extract for at least $1 \mathrm{~h}$ at $4{ }^{\circ} \mathrm{C}$ on rotating platform.

4. Rinse beads two times with $1 \mathrm{~mL}$ cold Lysis Buffer (with $0.5 \mathrm{mM}$ DTT and protease inhibitors).

5. On rotator in cold room wash beads two times for $5 \mathrm{~min}$ with $1 \mathrm{~mL}$ cold Lysis Buffer (with 0.5 mM DTT and protease inhibitors).

6. Wash five times with $1 \mathrm{~mL}$ Lysis Buffer (with $0.5 \mathrm{mM}$ DTT) without detergent (NP-40) or protease inhibitors. Remove as much supernatant as possible.

Note: The presence of detergents can interfere with mass spectrometry. Therefore, it is important to wash the sample thoroughly in detergent-free buffer after immunoprecipitation.

\section{Sample Buffer Elution: For Silver Staining \& Immunoblotting}

1. Elute beads by heating in $100 \mu \mathrm{L}$ of $2 \times$ Sample Buffer without DTT for $10 \mathrm{~min}$ at $70{ }^{\circ} \mathrm{C}$.

2. Pellet beads, transfer supernatant to a new tube, and add DTT to $100 \mathrm{mM}(1 / 9$ supernatant volume of 1 M DTT stock; Elution 1). 
3. Add $100 \mu \mathrm{L} 2 \times$ Sample Buffer with DTT to pelleted beads (Elution 2).

4. Boil both elution samples for $5 \mathrm{~min}$ and analyze by silver staining or immunoblot. Both elutions will contain immunoprecipitated proteins although amounts in each may vary; Elution 2 will have more $\operatorname{IgG}$ contamination than Elution 1.

Note: For immunoblots conducted using rabbit primary antibodies, the secondary antibody will detect any IgG released by the elution from the beads. For silver staining, load 5-10 $\mu \mathrm{L}$ directly. For immunoblots, load 5-10 $\mu \mathrm{L}$ of a 1/10 dilution made in Sample Buffer.

\section{Glycine Elution: For Mass Spectrometry}

1. After standard immunoprecipitation (see Section VI.B), elute beads three times with $150 \mu \mathrm{L} 100 \mathrm{mM}$ glycine (pH 2.6). Pool elutions and neutralize by adding 150 $\mu \mathrm{L} 2 \mathrm{M}$ Tris ( $\mathrm{pH} 8.5$ ). Neutralize the beads by washing two times with $150 \mu \mathrm{L}$ Lysis Buffer (without detergent) and pool with eluate. Total volume will be 900 $\mu \mathrm{L}$. Make sure you remove all the beads.

2. Add $1 / 5$ th volume $100 \%$ trichloroacetic acid (TCA; 200 $\mu \mathrm{L}$ ).

3. Leave samples at $4{ }^{\circ} \mathrm{C}$ overnight.

4. Spin for $30 \mathrm{~min}$ at maximum speed in microcentrifuge. Remove supernatant and spin again for $1 \mathrm{~min}$. Remove any residual supernatant with gel loading tip, leaving 5-10 $\mu \mathrm{L}$ behind.

5. Wash twice with $500 \mu \mathrm{L}$ cold acetone. Spin $10 \mathrm{~min}$ at maximum speed in microcentrifuge.

6. Dry the protein pellet by spinning briefly in a speed vac.

7. Freeze in liquid nitrogen and store at $-80{ }^{\circ} \mathrm{C}$. The protein pellet is suitable for direct mass spectrometric analysis.

8. After elution with glycine, the beads should be boiled in Sample Buffer and analyzed by silver staining/immunoblotting to assess elution efficiency.

\section{E. Urea Elution: For Mass Spectrometry}

Urea elution can also be used for mass spectrometry. In practice, we find that glycine elution works better for elution of the antigen from the antibody and for detection of the purified antigen in mass spectrometric analysis.

1. After standard immunoprecipitation (see Section VI.B), wash beads with Pre-urea Wash Buffer. Remove all residual supernatant.

2. Add $75 \mu \mathrm{L}$ Urea Elution Buffer and rotate for $30 \mathrm{~min}$ at RT.

3. Pellet beads and transfer eluate to a new tube. Re-pellet to ensure removal of all protein A beads.

4. Remove $50 \mu \mathrm{L}$ of elution and drop freeze in liquid nitrogen to send for mass spectrometry. Add Sample Buffer to the rest to run on a gel.

\section{Tandem Affinity Purification Using a LAP Tag}

As a first step, the extract is incubated with anti-GFP antibody-coupled protein A beads (Fig. 3A). For this purpose, we use in-house rabbit polyclonal anti-GFP antibodies generated by injecting purified GFP in rabbits. Recombinant GFP-binding domains from single-chain antibodies have also been used successfully for affinity purification of GFP-tagged proteins (Trinkle-Mulcahy et al., 2008). After immunoprecipitation of GFP, the fusion protein is 
released by TEV protease cleavage (Fig. 3A). The subsequent purification on S Protein agarose further enriches for complexes containing the fusion protein. Extract prepared from an untagged strain can serve as negative control for the TAP procedure.

\section{A. TEV Cleavage}

Perform immunoprecipitation using anti-GFP antibody-coupled beads as described in Section VI.B.

Note: At this stage, it is possible to elute bound material using glycine as described in Section VI.D. and compare the elution of the one-step GFP immunoprecipitation to the twostep LAP.

1. Pool beads into a single tube and fill with Lysis Buffer (with $300 \mathrm{mM} \mathrm{KCl}, 0.5 \mathrm{mM}$ DTT).

2. Add $\sim 30 \mu \mathrm{L}$ of purified TEV protease $(1 \mathrm{mg} / \mathrm{mL})$ and rock tubes for $4 \mathrm{~h}$ at $4{ }^{\circ} \mathrm{C}$. Add an additional $30 \mu \mathrm{L}$ of TEV and rock tubes overnight.

3. Pellet beads and transfer supernatant to a new tube. Add $350 \mu \mathrm{L}$ Lysis Buffer to beads to remove any residual cleaved protein.

\section{B. S Protein Agarose}

1. Wash tube of $85 \mu \mathrm{L} \mathrm{S}$ protein agarose three times with $1 \mathrm{~mL}$ Lysis Buffer (with $300 \mathrm{mM} \mathrm{KCl})$.

2. Add TEV protease eluted supernatant to $S$ protein agarose and rock for $3 \mathrm{~h}$ at $4{ }^{\circ} \mathrm{C}$.

3. Pellet beads and wash three times with Lysis Buffer (with $300 \mathrm{mM} \mathrm{KCl)}$ ).

4. Wash one time with Lysis Buffer with $100 \mathrm{mM} \mathrm{KCl}$ without detergent (NP-40).

\section{Sample Buffer Elution: For Silver Staining \& Immunoblotting}

Perform Sample Buffer Elution as described in Section VI.C.

\section{Urea Elution: For Mass Spectrometry}

Perform Urea Elution as described in Section VI.E.

\section{Mass Spectrometry \& Prioritization for Follow-up Experiments}

Protein mass spectrometry has made remarkable advances in the recent decade. We will not discuss the details of the methodology, which are extensively reviewed elsewhere (Cravatt $e t$ al., 2007; Yates et al., 2009). We typically do not separate proteins from immunoprecipitates on gels prior to mass spectrometry. Instead, the entire eluate is proteolytically digested and the peptide mixture is separated by multidimensional liquid chromatography. The mass/charge ratio of ionized peptides is determined in the first mass analyzer, and then the peptides are fragmented in the collision cell and passed through the second mass analyzer to determine amino acid sequence. As mentioned above, current methods can yield up to 1000 proteins in one-step immunoprecipitation performed using an antibody that passes generally accepted antibody specificity criteria. This abundance of information makes it challenging to sort relevant hits from background and necessitates redundant strategies. New technical developments, including labeling-based and label-free methods, may also aid in this effort. In practical terms, the challenge in analyzing protein mixtures by mass spectrometry lies primarily in developing a good working relationship with a mass spectrometry-focused laboratory or core facility. 
Prioritization of potential interactors from lists generated by mass spectrometry of immunoprecipiates/tandem affinity purifications for follow-up experiments is perhaps the greatest challenge faced in biochemical analysis of protein complexes. In this regard, it is helpful to think of the initial list of proteins identified as hits from a primary screen, with a variety of secondary screens being necessary to separate the wheat from the chaff.

Redundant strategies and elimination of common contaminants are important means for filtering such lists. In addition, the extensive genomic resources available in $C$. elegans that are archived on Wormbase provide an invaluable tool. Finally, the ability to rapidly test gene function is perhaps the most important, as it motivates in-depth analysis to validate the initially observed putative physical interaction.

\section{Summary}

Although genetic and cell biological analysis continue to be central to elucidating gene function in C. elegans, identifying protein-protein interactions is increasingly being employed to develop comprehensive understanding of cellular pathways. In this chapter, we discussed biochemical methods and outlined protocols currently used to isolate protein complexes in C. elegans.

\section{$X$. Solutions and Media}

\section{A. Worm Reagents}

- $\quad$ NGM agarose plates (100 $\mathrm{mm}$ and $60 \mathrm{~mm})$

$3 \mathrm{~g} \mathrm{NaCl}$

$25 \mathrm{~g}$ agarose

2.5 g peptone

$975 \mathrm{~mL} \mathrm{ddH} \mathrm{H}_{2} \mathrm{O}$

Autoclave $35 \mathrm{~min}$ and place in $55^{\circ} \mathrm{C}$ water bath.

When cooled sterilely add:

$1 \mathrm{~mL}$ cholesterol $(5 \mathrm{mg} / \mathrm{mL}$ in EtOH$)$

$1 \mathrm{~mL} 1 \mathrm{M} \mathrm{CaCl}_{2}$

$1 \mathrm{~mL}_{1} \mathrm{M} \mathrm{MgSO}_{4}$

$25 \mathrm{~mL} 1 \mathrm{M} \mathrm{KH}_{2} \mathrm{PO}_{4}(\mathrm{pH} 6.0)$

- $\quad M 9$

$10 \mathrm{~g} \mathrm{NaCl}$

$12 \mathrm{~g} \mathrm{Na}_{2} \mathrm{HPO}_{4}$

$6 \mathrm{~g} \mathrm{KH}_{2} \mathrm{PO}_{4}$

$0.5 \mathrm{~g} \mathrm{MgSO}_{4} \cdot 7 \mathrm{H}_{2} \mathrm{O}$

Add $\mathrm{ddH}_{2} \mathrm{O}$ to $2 \mathrm{~L}$ and autoclave $35 \mathrm{~min}$.

- $\quad 2 \mathrm{M} \mathrm{NaOH}$

- Bleach

Fischer Cat. \#SS290 (parafilm when not in use to minimize exposure to air and store at $4{ }^{\circ} \mathrm{C}$ ) 
- OP-50

\section{B. Large-Scale Liquid Culture}

- $60 \%(w / v)$ sucrose in M9

- $0.1 \mathrm{M} \mathrm{NaCl}$

- OP-50-1

streptomycin resistant $E$. coli strain

- $\quad L B(2 x)$

$100 \mathrm{~g}$ of LB

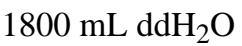

Autoclave $35 \mathrm{~min}$

- $\quad L B+50 \mu \mathrm{g} / \mathrm{mL}$ streptomycin

- $\quad S$ Basal $(1 \mathrm{~L})$

$5.9 \mathrm{~g} \mathrm{NaCl}$

$50 \mathrm{~mL}$ of $1 \mathrm{M} \mathrm{KH}_{2} \mathrm{PO}_{4}(\mathrm{pH} 6.0$ )

Add $\mathrm{ddH}_{2} \mathrm{O}$ to $1 \mathrm{~L}$

Split into two $500 \mathrm{~mL}$ bottles; to each bottle add $0.5 \mathrm{~mL}$ cholesterol $(5 \mathrm{mg} /$ $\mathrm{mLin} \mathrm{EtOH}$; should form a light cloudy precipitate).

Autoclave and store at RT.

- Trace Metals Solution

\begin{tabular}{lll}
\hline Disodium EDTA & $1.86 \mathrm{~g}$ & $(5 \mathrm{mM})$ \\
$\mathrm{FeSO}_{4} \cdot 7 \mathrm{H}_{2} \mathrm{O}$ & $0.69 \mathrm{~g}$ & $(2.5 \mathrm{mM})$ \\
$\mathrm{MnCl}_{2} \cdot 4 \mathrm{H}_{2} \mathrm{O}$ & $0.2 \mathrm{~g}$ & $(1 \mathrm{mM})$ \\
$\mathrm{ZnSO}_{4} \cdot 7 \mathrm{H}_{2} \mathrm{O}$ & $0.29 \mathrm{~g}$ & $(1 \mathrm{mM})$ \\
$\mathrm{CuSO}_{4} \cdot 5 \mathrm{H}_{2} \mathrm{O}$ & $0.025 \mathrm{~g}$ & $(0.1 \mathrm{mM})$ \\
\hline
\end{tabular}

Dissolve in $1 \mathrm{~L}$ water; filter sterilize, aliquot into $50 \mathrm{~mL}$ conicals, and store in dark.

- 1 M potassium citrate ( $\mathrm{pH} 6.0)$

$268.8 \mathrm{~g}$ tripotassium citrate

$26.3 \mathrm{~g}$ citric acid monohydrate

Add $\mathrm{ddH}_{2} \mathrm{O}$ to $900 \mathrm{~mL}$, adjust $\mathrm{pH}$ to 6.0 using $10 \mathrm{~N} \mathrm{KOH}$ and add $\mathrm{ddH}_{2} \mathrm{O}$ to 1 L. Autoclave and store at RT.

- $\quad 1 \mathrm{M} \mathrm{MgSO}_{4}$

- $\quad 1 \mathrm{M} \mathrm{CaCl}_{2}$

- Complete S Basal

Working under sterile conditions in the laminar flow hood add the following to $500 \mathrm{~mL}$ S Basal: 
$5 \mathrm{~mL} 1 \mathrm{M}$ potassium citrate $(\mathrm{pH} 6.0)$

$5 \mathrm{~mL}$ Trace Metals Solution

$1.5 \mathrm{~mL}_{1} \mathrm{M} \mathrm{MgSO}_{4}$

$1.5 \mathrm{~mL} 1 \mathrm{M} \mathrm{CaCl}_{2}$

\section{Isolation of Nuclei from Embryos}

- $30 \%(w / v)$ sucrose in Nuclei Buffer

- Embryo Buffer

25 mM Hepes $\mathrm{KOH}$ (pH 7.6)

$118 \mathrm{mM} \mathrm{NaCl}$

$48 \mathrm{mM} \mathrm{KCl}$

$2 \mathrm{mM} \mathrm{CaCl}_{2}$

$2 \mathrm{mM} \mathrm{MgCl}{ }_{2}$

- $\quad$ Nuclei Buffer

$10 \mathrm{mM}$ Tris: $\mathrm{HCl}(\mathrm{pH} 8.0)$

$80 \mathrm{mM} \mathrm{KCl}$

2 mM EDTA

$0.75 \mathrm{mM}$ spermidine

$0.3 \mathrm{mM}$ spermine

Spermine and spermidine are prepared as $1 \mathrm{M}$ stocks in $\mathrm{ddH}_{2} \mathrm{O}$ and stored at $-20{ }^{\circ} \mathrm{C}$. Add immediately before use.

Add 1 tablet Complete EDTA-Free Protease Inhibitor Cocktail Tablets (Roche Applied Science, Cat. \#1873580) per $10 \mathrm{~mL}$ buffer just prior to use.

- $10 \%(w / v)$ digitonin

(Sigma, Cat. \#37006) stock solution is prepared in $\mathrm{ddH}_{2} \mathrm{O}$ by boiling and

filtering. Store aliquots at $-20^{\circ} \mathrm{C}$. Briefly boil, chill on ice, and add to Nuclei Buffer immediately before use.

- Chitinase

Dilute in Embryo Buffer at $2 \mathrm{U} / \mathrm{mL}$ and store aliquots at $-20{ }^{\circ} \mathrm{C}$. The efficiency of chitinase treatment varies and the optimal length of digestion should be re-determined for each new batch.

- Hoechst 33342

\section{Single-step Immunoprecipitation}

Antibody coupling

- 10-50 $\mu \mathrm{g}$ of affinity-purified antibody

- $\quad$ Affi-Prep Protein A beads (Biorad Cat. \#156-0006)

- $\quad$ PBST (PBS + 0.1\% Tween-20)

- 1 M sodium borate ( $\mathrm{pH}$ 9.0) 
Dissolve $61.8 \mathrm{~g}$ of boric acid in $800 \mathrm{~mL}$ of $\mathrm{ddH}_{2} \mathrm{O}$ and adjust the $\mathrm{pH}$ to 9.0 with $\mathrm{NaOH}$ pellets. Bring volume to $1 \mathrm{~L}$ with $\mathrm{ddH}_{2} \mathrm{O}$ and filter to sterilize. Store at RT.

- $\quad 0.2$ M sodium borate ( $p H$ 9.0)

Dilute from a stock of $1 \mathrm{M}$ sodium borate ( $\mathrm{pH} 9.0)$.

- $220 \mathrm{mM} \mathrm{DMP}$

(Sigma Cat. \#D8388; FW259.2; stored in a dessicated box at $-20{ }^{\circ} \mathrm{C}$ ) Let bottle sit tightly closed at RT for 20 min before opening. Weigh out DMP and leave dry until just before use. Resuspend in appropriate volume of $0.2 \mathrm{M}$ sodium borate ( $\mathrm{pH} 9.0)$ and add immediately to the bead suspension (e.g., for $34 \mathrm{mg}$ DMP add $596 \mu \mathrm{L}$ sodium borate).

- $\quad 0.2 \mathrm{M}$ ethanolamine, $0.2 \mathrm{M} \mathrm{NaCl}(\mathrm{pH} 8.5)$

Dissolve $12.2 \mathrm{~g}$ of ethanolamine and $11.7 \mathrm{~g}$ of $\mathrm{NaCl}$ in $\mathrm{ddH}_{2} \mathrm{O}$, adjust the $\mathrm{pH}$ to 8.5 with $\mathrm{HCl}$. Add $\mathrm{ddH}_{2} \mathrm{O}$ to $1 \mathrm{~L}$ and filter to sterilize. Store at RT.

Immunoprecipitation

- $100 \mathrm{mM}$ glycine ( $\mathrm{pH}$ 2.6)

Dissolved $7.5 \mathrm{~g}$ glycine in $800 \mathrm{~mL}$ of $\mathrm{ddH}_{2} \mathrm{O}$ and adjust $\mathrm{pH}$ to 2.6 with $\mathrm{HCl}$. Add $\mathrm{ddH}_{2} \mathrm{O}$ to $1 \mathrm{~L}$. Filter to sterilize and store at $4{ }^{\circ} \mathrm{C}$.

- Lysis Buffer

50 mM HEPES (pH 7.4)

1 mM EGTA

$1 \mathrm{mM} \mathrm{MgCl} l_{2}$

$100 \mathrm{mM} \mathrm{KCl}$

$10 \%$ glycerol

$0.05 \% \mathrm{NP}-40$

DTT goes off with time, so add it to the buffer just before the experiment.

Just prior to use add one tablet Complete EDTA-Free Protease Inhibitor Cocktail Tablets (Roche Applied Science, \#1873580) to $12 \mathrm{~mL}$ Lysis Buffer.

Use Lysis Buffer with $300 \mathrm{mM}$ KCL as indicated in text.

- $3 x$ Sample Buffer

$6 \%$ SDS

$240 \mathrm{mM}$ Tris (pH 6.8)

$30 \%$ Glycerol

$\sim 0.04 \%$ (w/v) Bromophenol blue

Add $50 \mu \mathrm{L} \mathrm{100 \%} \mathrm{2-ME} \mathrm{to} 1 \mathrm{~mL}$ just before use.

- $1 M D T T$

Dissolve $7.7 \mathrm{~g}$ DTT in $50 \mathrm{~mL}$ sterile $\mathrm{ddH}_{2} \mathrm{O}$. Store $1 \mathrm{~mL}$ aliquots at $-20{ }^{\circ} \mathrm{C}$.

- Pre-urea Wash Buffer 
$50 \mathrm{mM}$ Tris $(\mathrm{pH} 8.5)$

1 mM EGTA

$75 \mathrm{mM} \mathrm{KCl}$

Filter to sterilize and store at RT.

- Urea Elution Buffer

$50 \mathrm{mM}$ Tris $(\mathrm{pH} 8.5)$

$8 \mathrm{M}$ urea (Invitrogen Cat. \# 15505-035)

Store at RT and make fresh on the day of use.

- $2 M \operatorname{Tris}(\mathrm{pH} 8.5)$

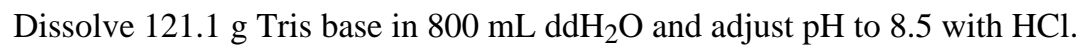

Add $\mathrm{ddH}_{2} \mathrm{O}$ to $1 \mathrm{~L}$. Sterilize by autoclaving and store at RT.

- $\quad 100 \%$ TCA (Sigma Aldrich Cat. \# T0699100 mL)

\section{E. Tandem Affinity Purification using a LAP Tag}

- GFP antibody

- TEV protease $6 H i s-T E V$ protease $(1 \mathrm{mg} / \mathrm{mL}$ stock), purified using nickelnitrilotriacetic acid (Ni-NTA) agarose and gel filtration (Kapust et al., 2001; Parks et al., 1995), or available from Invitrogen (Cat. \#12575-015)

- $\quad$ S protein agarose (Novagen Cat. \#69704)

\section{Equipment}

- $\quad 2.8$ L Fernbach flasks

- microcentrifuge

- $\quad 0.5 \mathrm{~mL}$ and $1.5 \mathrm{~mL}$ microcentrifuge tubes

- $1 \mathrm{~L}$ centrifuge bottles

- $1.5 \mathrm{~mL}$ screw-cap tubes

- $\quad 15 \mathrm{~mL}$ and $50 \mathrm{~mL}$ conicals

- Dissecting microscope

- Graduated cylinders

- Mortar and pestle

- Ultracentrifuge with TLA100.3 rotor (Beckman, \#349622)

- Sonicator with pulse capacity (e.g., Branson Digital Sonifier)

- Wheaton dounce homogenizer with pestle B

- Cooling shaker (Kuhner Shaker)

- Bransonic Ultrasonic Cleaner 3510

- Liquid nitrogen dewar flask 


\section{ABBREVIATIONS}

$\begin{array}{ll}\text { APC } & \text { Anaphase-promoting complex } \\ \text { CBP } & \text { Calmodulin-binding peptide } \\ \text { ChIP } & \text { Chromatin Immunoprecipitation } \\ \text { DMP } & \text { Dimethylpimelidimate } \\ \text { dsRNA } & \text { Double stranded RNA } \\ \text { GST } & \text { Glutathione S-transferase } \\ \text { h } & \text { Hour } \\ \text { IP } & \text { Immunoprecipitation } \\ \text { LAP } & \text { Localization and Affinity Purification } \\ \text { MosSCI } & \text { Mos1 mediated Single Copy transgene Insertion } \\ \text { nAChR } & \text { Nicotinic acetylcholine receptor } \\ \text { RNAi } & \text { RNA interference } \\ \text { RT } & \text { Room temperature } \\ \text { TAP } & \text { Tandem Affinity Purification } \\ \text { TEV } & \text { Tobacco etch virus }\end{array}$

\section{Acknowledgments}

We acknowledge support of grants from the NIH to A.D. (GM074215) and K.O. (GM074207), and by funding from the Ludwig Institute for Cancer Research to A.D. and K.O. This work is supported by the National Center for Research Resources of the National Institutes of Health by a grant to T.N.D. entitled "Comprehensive Biology: Exploiting the Yeast Genome" (P41 RR11823). E.Z. is supported by a research fellowship from the DFG (ZA619/1-1).

\section{References}

Audhya A, Desai A. Proteomics in Caenorhabditis elegans. Brief Funct. Genomic Proteomic. 2008; 7:205-210. [PubMed: 18372286]

Audhya A, Hyndman F, McLeod IX, Maddox AS, Yates JR III, Desai A, Oegema K. A complex containing the Sm protein CAR-1 and the RNA helicase CGH-1 is required for embryonic cytokinesis in Caenorhabditis elegans. J. Cell. Biol. 2005; 171:267-279. [PubMed: 16247027]

Beanan MJ, Strome S. Characterization of a germ-line proliferation mutation in. C. elegans. Development. 1992; 116:755-766. [PubMed: 1289064]

Cassada R, Isnenghi E, Culotti M, von Ehrenstein G. Genetic analysis of temperature-sensitive embryogenesis mutants in Caenorhabditis elegans. Dev. Biol. 1981; 84:193-205. [PubMed: 7250492]

Cheeseman IM, Desai A. A combined approach for the localization and tandem affinity purification of protein complexes from metazoans. Sci. STKE. 2005; 2005:11.

Cheeseman IM, Niessen S, Anderson S, Hyndman F, Yates JR III, Oegema K, Desai A. A conserved protein network controls assembly of the outer kinetochore and its ability to sustain tension. Genes Dev. 2004; 18:2255-2268. [PubMed: 15371340]

Chowdhury PS. DNA immunization as a means to generate antibodies to proteins. Methods Mol. Biol. 2003; 207:57-62. [PubMed: 12412467]

Cinar H, Keles S, Jin Y. Expression profiling of GABAergic motor neurons in Caenorhabditis elegans. Curr. Biol. 2005; 15:340-346. [PubMed: 15723795] 
Colosimo ME, Brown A, Mukhopadhyay S, Gabel C, Lanjuin AE, Samuel AD, Sengupta P. Identification of thermosensory and olfactory neuron-specific genes via expression profiling of single neuron types. Curr. Biol. 2004; 14:2245-2251. [PubMed: 15620651]

Cravatt BF, Simon GM, Yates JR III. The biological impact of mass-spectrometry-based proteomics. Nature. 2007; 450:991-1000. [PubMed: 18075578]

Dammermann A, Maddox PS, Desai A, Oegema K. SAS-4 is recruited to a dynamic structure in newly forming centrioles that is stabilized by the gamma-tubulin-mediated addition of centriolar microtubules. J. Cell. Biol. 2008; 180:771-785. [PubMed: 18299348]

Dammermann A, Pemble H, Mitchell BJ, McLeod I, Yates JR, Kintner C, Desai AB, Oegema K. The hydrolethalus syndrome protein HYLS-1 links core centriole structure to cilia formation. Genes Dev. 2009; 23:2046-2059. [PubMed: 19656802]

Desai A, Rybina S, Muller-Reichert T, Shevchenko A, Hyman A, Oegema K. KNL-1 directs assembly of the microtubule-binding interface of the kinetochore in C. elegans. Genes Dev. 2003; 17:24212435. [PubMed: 14522947]

Duchaine TF, Wohlschlegel JA, Kennedy S, Bei Y, Conte D Jr, Pang K, Brownell DR, Harding S, Mitani S, Ruvkun G, et al. Functional proteomics reveals the biochemical niche of C. elegans DCR-1 in multiple small-RNA-mediated pathways. Cell. 2006; 124:343-354. [PubMed: 16439208]

Edgar LG. Blastomere culture and analysis. Methods Cell Biol. 1995; 48:303-321. [PubMed: 8531731]

Fernandez AG, Gunsalus KC, Huang J, Chuang LS, Ying N, Liang HL, Tang C, Schetter AJ, Zegar C, Rual JF, et al. New genes with roles in the C. elegans embryo revealed using RNAi of ovaryenriched ORFeome clones. Genome Res. 2005; 15:250-259. [PubMed: 15687288]

Fernandez AG, Mis EK, Bargmann BO, Birnbaum KD, Piano F. Automated sorting of live C. elegans using laFACS. Nat. Methods. 2010; 7:417-418. [PubMed: 20436474]

Frokjaer-Jensen C, Davis MW, Hopkins CE, Newman BJ, Thummel JM, Olesen SP, Grunnet M, Jorgensen EM. Single-copy insertion of transgenes in Caenorhabditis elegans. Nat. Genet. 2008; 40:1375-1383. [PubMed: 18953339]

Gassmann R, Essex A, Hu JS, Maddox PS, Motegi F, Sugimoto A, O'Rourke SM, Bowerman B, McLeod I, Yates JR, et al. A new mechanism controlling kinetochore-microtubule interactions revealed by comparison of two dynein-targeting components: SPDL-1 and the Rod/Zwilch/Zw10 complex. Genes Dev. 2008; 22:2385-2399. [PubMed: 18765790]

Golden A, Sadler PL, Wallenfang MR, Schumacher JM, Hamill DR, Bates G, Bowerman B, Seydoux G, Shakes DC. Metaphase to anaphase (mat) transition-defective mutants in Caenorhabditis elegans. J. Cell. Biol. 2000; 151:1469-1482. [PubMed: 11134076]

Gottschalk A, Almedom RB, Schedletzky T, Anderson SD, Yates JR III, Schafer WR. Identification and characterization of novel nicotinic receptor-associated proteins in Caenorhabditis elegans. EMBO J. 2005; 24:2566-2578. [PubMed: 15990870]

Green RA, Audhya A, Pozniakovsky A, Dammermann A, Pemble H, Monen J, Portier N, Hyman A, Desai A, Oegema K. Expression and imaging of fluorescent proteins in the C. elegans gonad and early embryo. Methods Cell Biol. 2008; 85:179-218. [PubMed: 18155464]

Green RA, Kao HL, Audhya A, Arur S, Mayers JR, Fridolfsson HN, Schulman M, Schloissnig S, Niessen S, Laband K, et al. A high-resolution C. elegans essential gene network based on phenotypic profiling of a complex tissue. Cell. 2011; 145:470-482. [PubMed: 21529718]

Harlow, EL.; David; Harlow, E.; Lane, D. Using Antibodies: A Laboratory Manual. New York: Cold Spring Harbor Laboratory Press; 1999.

Hope, IA. C. elegans: A Practical Approach. Oxford \& New York: Oxford University Press; 1999.

Huang LS, Sternberg PW. Genetic dissection of developmental pathways. WormBook. 2006; 14:1-19. [PubMed: 18050452]

Hubner NC, Bird AW, Cox J, Splettstoesser B, Bandilla P, Poser I, Hyman A, Mann M. Quantitative proteomics combined with BAC TransgeneOmics reveals in vivo protein interactions. J. Cell Biol. 2010; 189:739-754. [PubMed: 20479470] 
Kamath RS, Fraser AG, Dong Y, Poulin G, Durbin R, Gotta M, Kanapin A, Le Bot N, Moreno S, Sohrmann M, et al. Systematic functional analysis of the Caenorhabditis elegans genome using RNAi. Nature. 2003; 421:231-237. [PubMed: 12529635]

Kapust RB, Tozser J, Fox JD, Anderson DE, Cherry S, Copeland TD, andWaugh DS. Tobacco etch virus protease: mechanism of autolysis and rational design of stable mutants with wild-type catalytic proficiency. Protein Eng. 2001; 14:993-1000. [PubMed: 11809930]

Kelly WG, Fire A. Chromatin silencing and the maintenance of a functional germline in Caenorhabditis elegans. Development. 1998; 125:2451-2456. [PubMed: 9609828]

McNally K, Audhya A, Oegema K, McNally FJ. Katanin controls mitotic and meiotic spindle length. J. Cell Biol. 2006; 175:881-891. [PubMed: 17178907]

Mello C, Fire A. DNA transformation. Methods Cell Biol. 1995; 48:451-482. [PubMed: 8531738]

Mello CC, Kramer JM, Stinchcomb D, Ambros V. Efficient gene transfer. in C. elegans: extrachromosomal maintenance and integration of transforming sequences. EMBO J. 1991; 10:3959-3970. [PubMed: 1935914]

Moresco JJ, Carvalho PC, Yates JR III. Identifying components of protein complexes in C elegans using co-immunoprecipitation and mass spectrometry. J. Proteomics. 2010; 73(11):2198-2204. [PubMed: 20546956]

Parks TD, Howard ED, Wolpert TJ, Arp DJ, Dougherty WG. Expression and purification of a recombinant tobacco etch virus NIa proteinase: biochemical analyses of the full-length and a naturally occurring truncated proteinase form. Virology. 1995; 210:194-201. [PubMed: 7793070]

Piano F, Schetter AJ, Mangone M, Stein L, Kemphues KJ. RNAi analysis of genes expressed in the ovary of Caenorhabditis elegans. Curr. Biol. 2000; 10:1619-1622. [PubMed: 11137018]

Piano F, Schetter AJ, Morton DG, Gunsalus KC, Reinke V, Kim SK, Kemphues KJ. Gene clustering based on RNAi phenotypes of ovary-enriched genes in C. elegans. Curr. Biol. 2002; 12:19591964. [PubMed: 12445391]

Polanowska J, Martin JS, Fisher R, Scopa T, Rae I, Boulton SJ. Tandem immunoaffinity purification of protein complexes from Caenorhabditis elegans. Biotechniques. 2004; 36:778-780. 782. [PubMed: 15152596]

Praitis V, Casey E, Collar D, Austin J. Creation of low-copy integrated transgenic lines in Caenorhabditis elegans. Genetics. 2001; 157:1217-1226. [PubMed: 11238406]

Rigaut G, Shevchenko A, Rutz B, Wilm M, Mann M, Seraphin B. A generic protein purification method for protein complex characterization and proteome exploration. Nat. Biotechnol. 1999; 17:1030-1032. [PubMed: 10504710]

Schaffer U, Schlosser A, Muller KM, Schafer A, Katava N, Baumeister R, Schulze E. SnAvi - a new tandem tag for high-affinity protein-complex purification. Nucleic Acids Res. 2010; 38:e91. [PubMed: 20047968]

Seydoux G, Strome S. Launching the germline in Caenorhabditis elegans: regulation of gene expression in early germ cells. Development. 1999; 126:3275-3283. [PubMed: 10393107]

Sonnichsen B, Koski LB, Walsh A, Marschall P, Neumann B, Brehm M, Alleaume AM, Artelt J, Bettencourt P, Cassin E, et al. Full-genome RNAi profiling of early embryogenesis in Caenorhabditis elegans. Nature. 2005; 434:462-469. [PubMed: 15791247]

Sulston JE, Schierenberg E, White JG, Thomson JN. The embryonic cell lineage of the nematode Caenorhabditis elegans. Dev. Biol. 1983; 100:64-119. [PubMed: 6684600]

Trinkle-Mulcahy L, Boulon S, Lam YW, Urcia R, Boisvert FM, Vandermoere F, Morrice NA, Swift S, Rothbauer U, Leonhardt $\mathrm{H}$, et al. Identifying specific protein interaction partners using quantitative mass spectrometry and bead proteomes. J. Cell. Biol. 2008; 183:223-239. [PubMed: 18936248]

Yates JR, Ruse CI, Nakorchevsky A. Proteomics by mass spectrometry: approaches, advances, and applications. Annu. Rev. Biomed. Eng. 2009; 11:49-79. [PubMed: 19400705]

Zhang Y, Ma C, Delohery T, Nasipak B, Foat BC, Bounoutas A, Bussemaker HJ, Kim SK, Chalfie M. Identification of genes expressed in C. elegans touch receptor neurons. Nature. 2002; 418:331335. [PubMed: 12124626] 

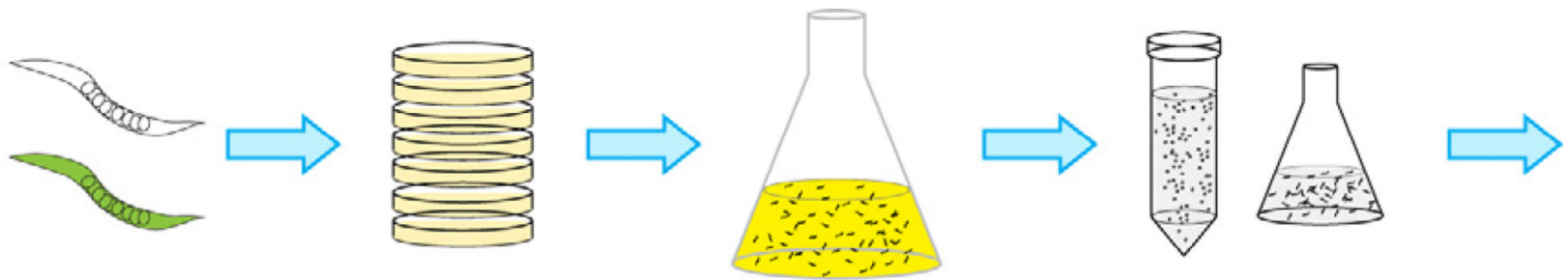

Starved Larvae

Unsynchronized

Starter Culture

$\sim 10$ days

$\sim 4$ days

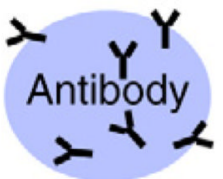

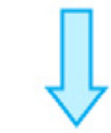
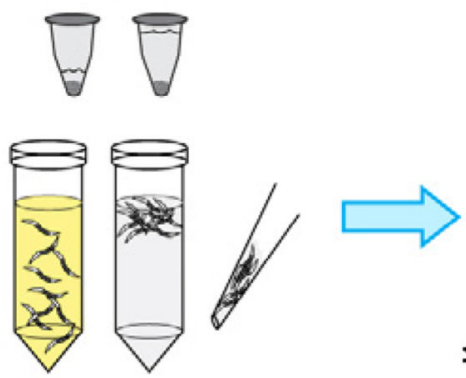

Isolate Embryos

\& Hatch L1 Larvae

1 day

\section{Several Rounds of Synchronized Liquid Culture}

\section{Extract Preparation Immunoprecipitation}
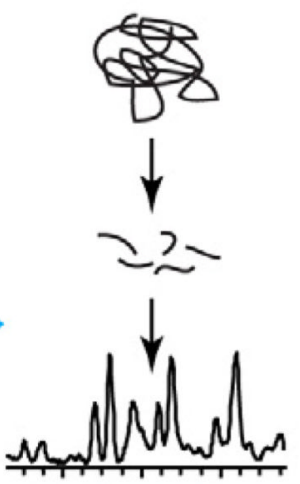

Mass Spectrometry

$\sim 1$ week

Fig. 1.

Experimental outline for protein complex identification in C. elegans. Wild-type or LAPtagged strain is grown on NGM plates until larvae are starved. With starved larvae an unsynchronized starter culture is inoculated. Embryos are isolated by bleaching and hatched in the absence of food to obtain starved L1 larvae. Starved L1 larvae are used to set up six synchronized liquid cultures. After several rounds of synchronized liquid culture, when sufficient amounts of worms/embryos are obtained, the extract is prepared and protein complexes are purified by immunoprecipitation and analyzed by mass spectrometry. Approximate time for each experiment is indicated. (See color plate.) 


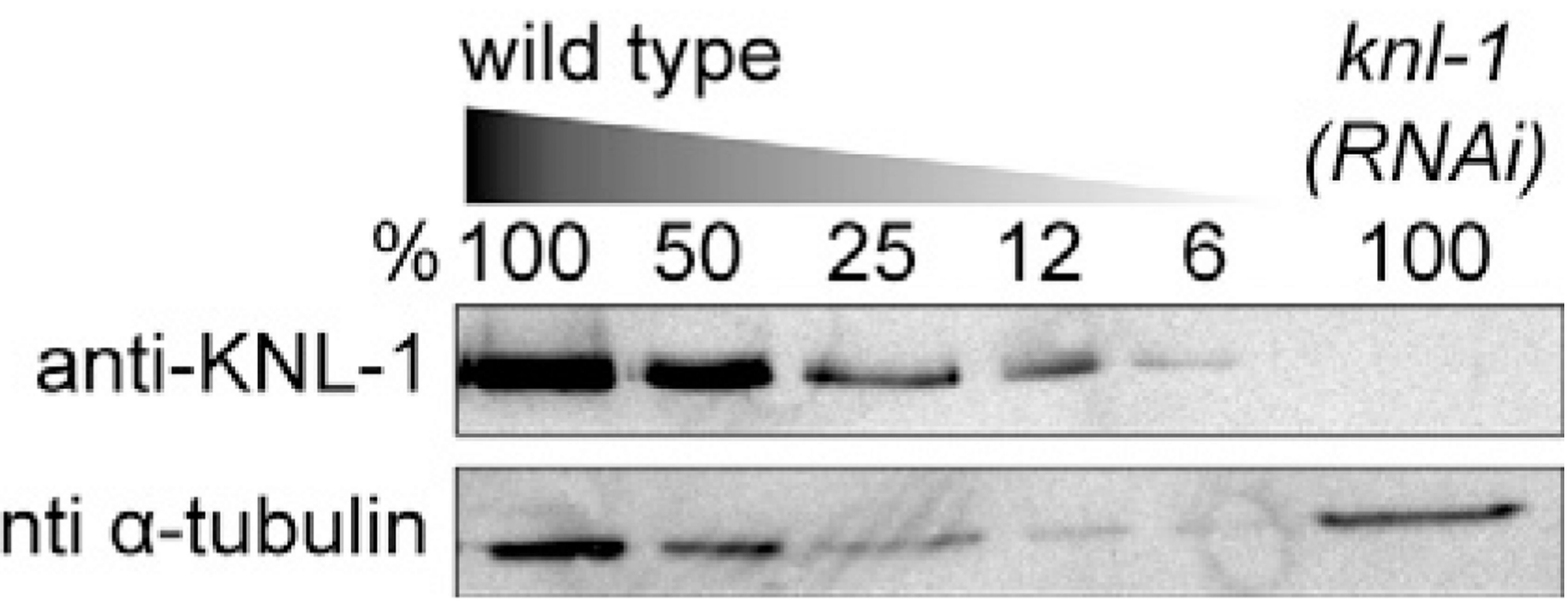

Fig. 2.

Immunoblot of wild-type and knl-1(RNAi) adult extract probed using anti-KNL-1 and anti $\alpha$ tubulin antibodies. A serial dilution of wild-type extract was loaded to determine the efficiency of KNL-1 depletion. 


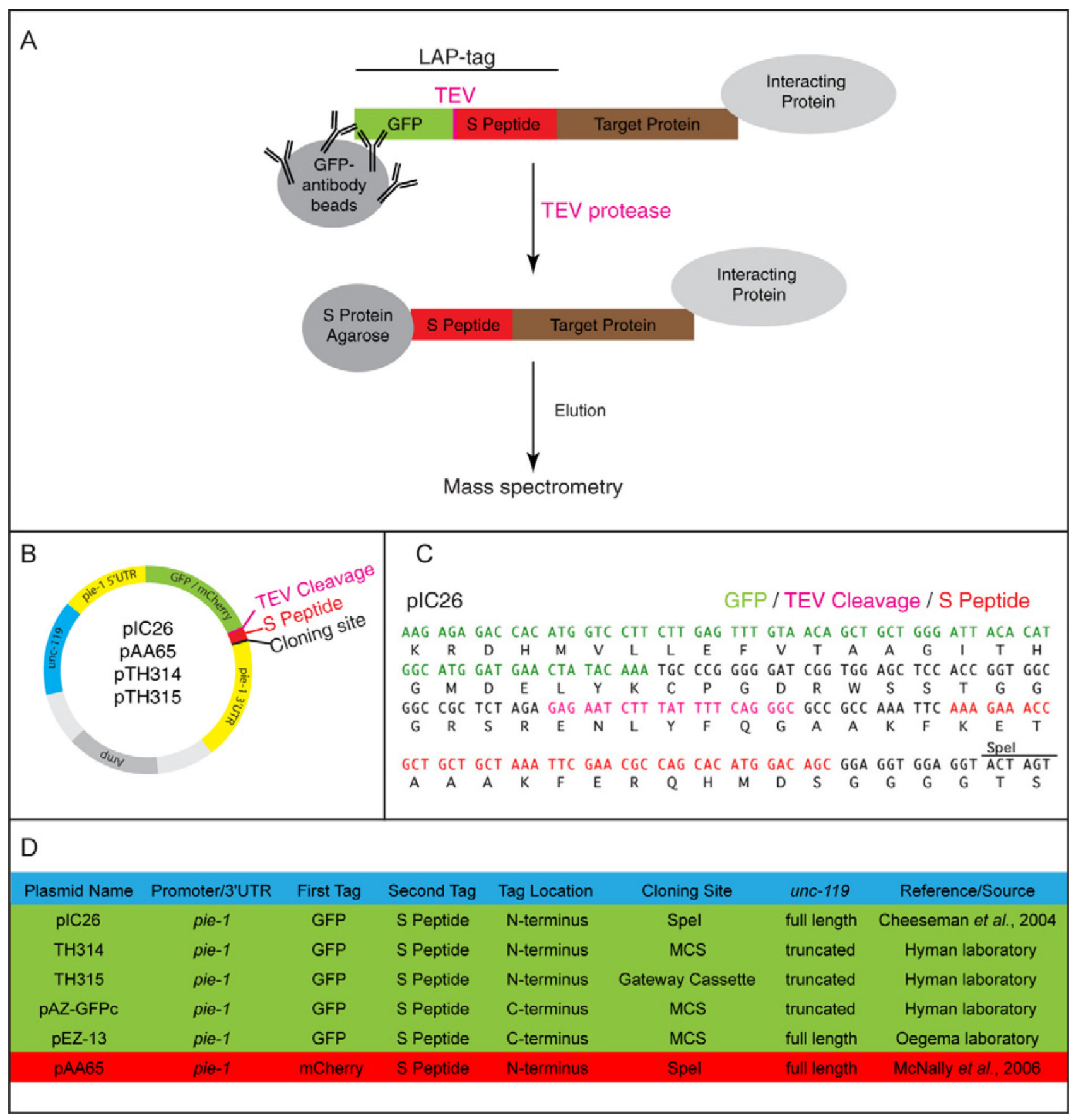

Fig. 3.

TAP strategy and cloning vectors. A) The LAP-tagged target protein is first purified with anti-GFP antibody coupled beads. LAP-tagged target protein and interacting proteins are released from the beads by TEV protease cleavage and purified over $\mathrm{S}$ protein agarose. Interacting proteins are eluted from the beads and analyzed by mass spectrometry. B) Schematic vector map illustrating the common features of the standard LAP cloning vectors. C) Partial sequence of pIC26: in green 3' end of GFP, pink TEV protease cleavage site, red $\mathrm{S}$ peptide. The SpeI cloning site is indicated. D) Overview of the different features of the TAP cloning vectors. (See color plate.) 


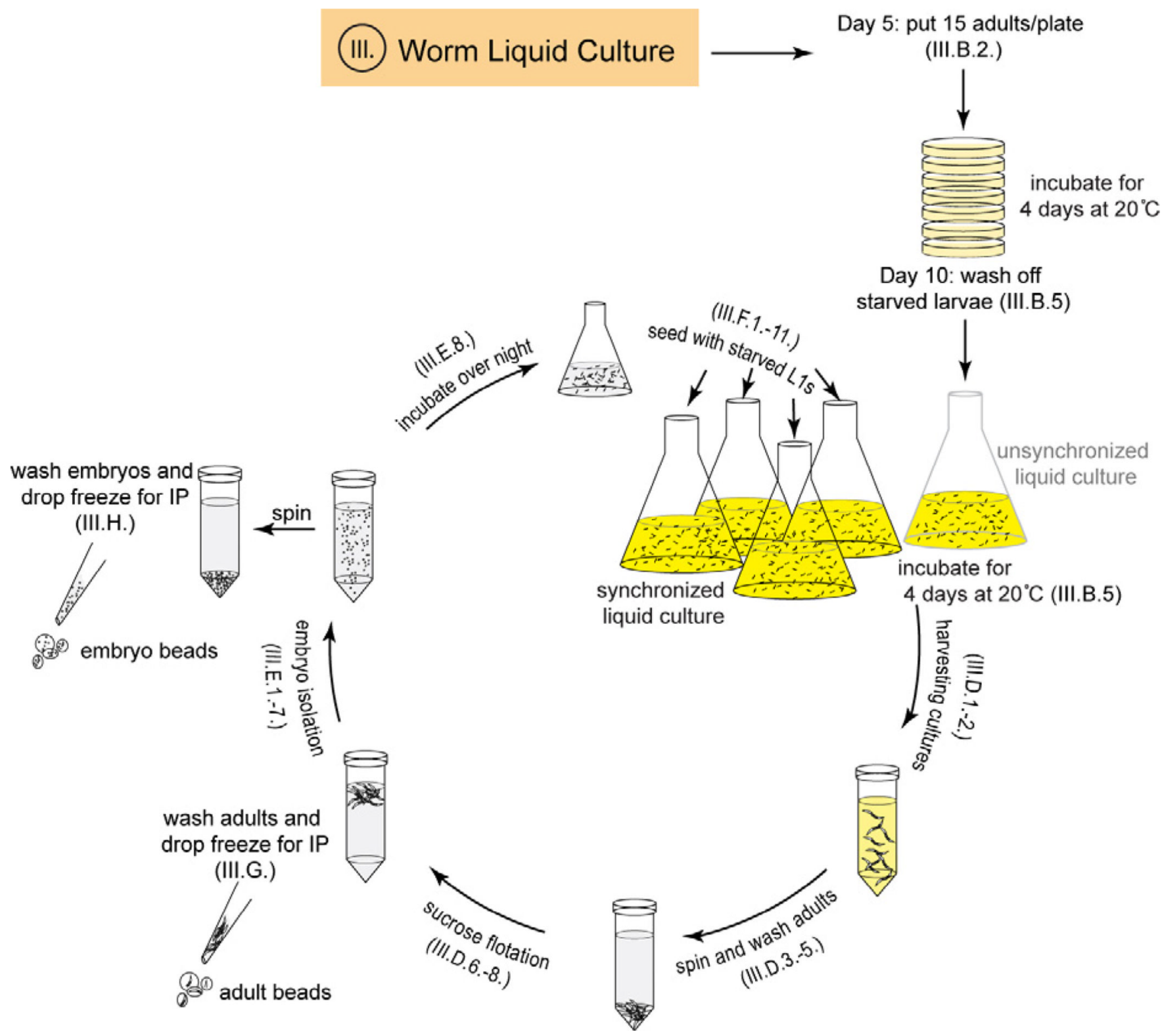

Fig. 4.

Schematic overview of worm liquid culture (see Section III.). Fifteen axenized adults are grown $\sim 4$ days on 100 mm NGM agarose plates until larvae are starved (Section III.B.2.). Starved larvae are washed off the NGM plates and used to inoculate an unsynchronized liquid culture (Section III.B.5.). After 4 days, adult worms with 10-15 embryos are harvested, washed with M9, and cleaned by sucrose flotation (Section III.D.1.-8.). Embryos are isolated by bleaching and incubated overnight for L1 larvae to hatch (Section III.E.1.-8.). Starved L1 larvae are used to inoculate synchronized liquid culture (Section III.F.1.-11.). Harvested worms (Section III.G.) and embryos (Section III.H.) are drop frozen in liquid nitrogen for subsequent extract preparation. Roman numeral indicates corresponding section. (See color plate.) 


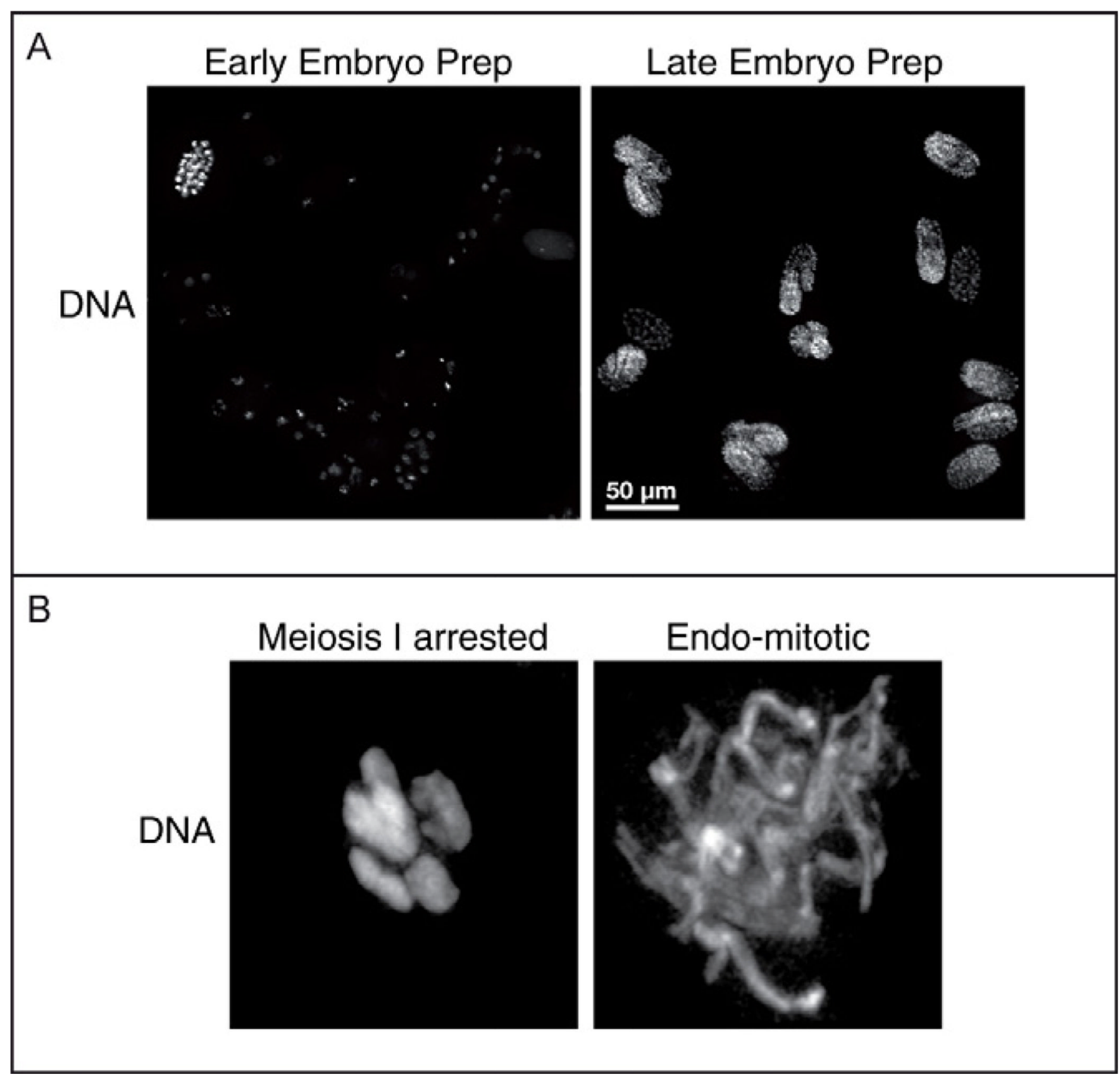

Fig. 5.

A) Early and late embryo preparation stained with Hoechst. B) Meiosis I arrested and endomitotic chromosomes stained with Hoechst. 


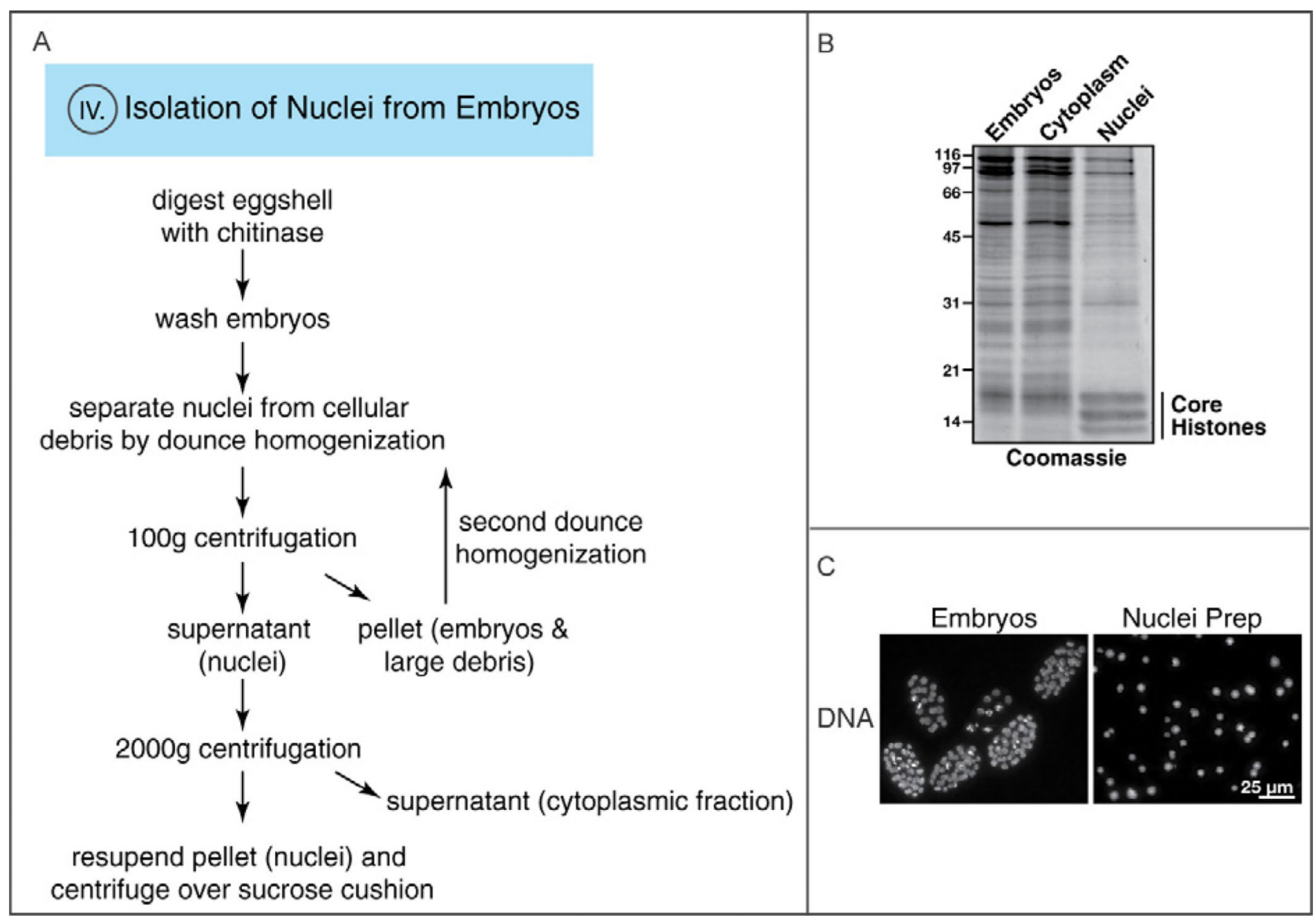

Fig. 6.

A) Experimental outline for nuclei isolation. Eggshell of the embryos is digested by chitinase treatment and embryos are washed. Dounce homogenization in hypotonic buffer separates the nuclei from cellular debris. Hundred $\times g$ centrifugation pellets embryos and cellular debris, which are subject to a second dounce homogenization. The supernatant containing the nuclei is centrifuged at $2000 \mathrm{~g}$ to pellet the nuclei. Nuclei are finally purified by centrifugation over a sucrose cushion. Roman numeral indicates corresponding section. B) Embryos, cytoplasmic fraction, and isolated nuclei stained with Coomassie. Histones are enriched in the isolated nuclei. C) Embryo and nuclei preparation stained with Hoechst. (For color version of this figure, the reader is referred to the web version of this book.) 


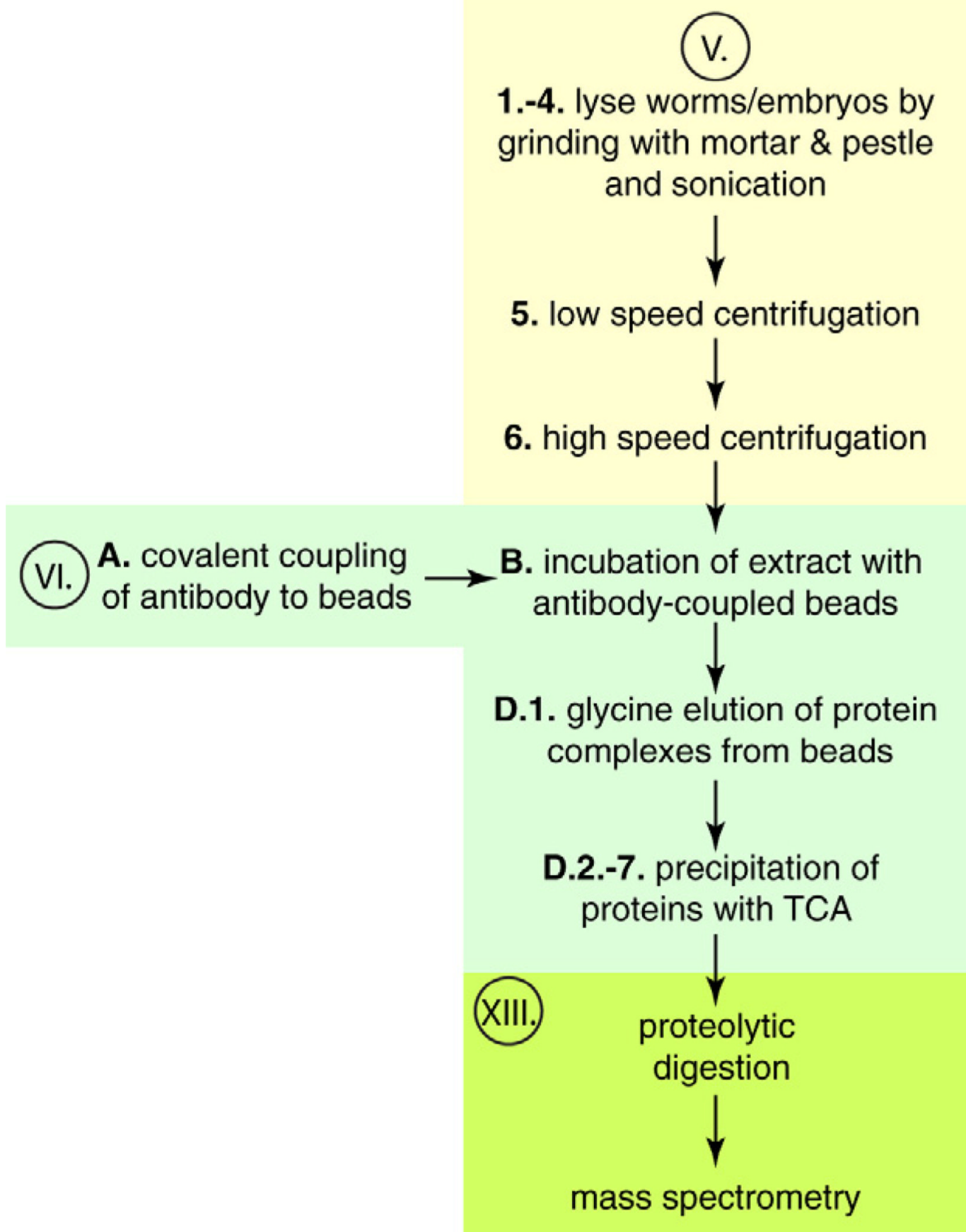

Fig. 7.

Experimental outline for protein complex purification. Roman numerals indicate the corresponding sections. A crude extract is generated by grinding and sonicating the worms and embryos (Section V.1.-4.). Two consecutive centrifugations clear the extract from debris and membranes (Section V.5.-6.). Antibodies are covalently coupled to beads (Section VI.A.) and extract is incubated with antibody-coupled beads (Section VI.B.). Protein complexes are eluted with glycine (Section VI.D.1.) and precipitated with TCA (Section VI.D.2.-7.). Prior to mass spectrometry the eluate is proteolytically digested (Section VIII.). (For color version of this figure, the reader is referred to the web version of this book.) 


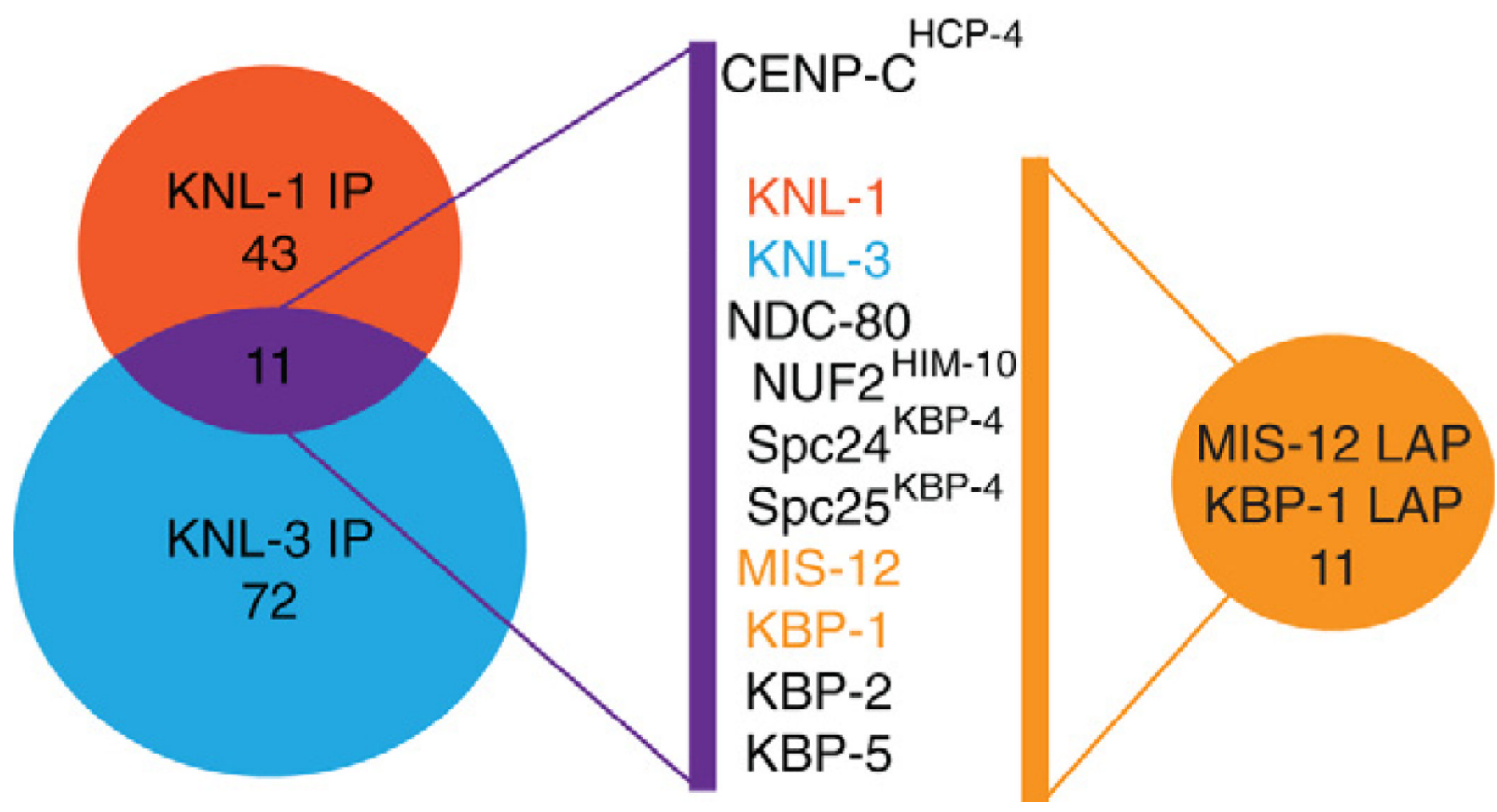

Fig. 8.

Identification of 10-protein kinetochore complex. Immunoprecipitation of KNL-1 and KNL-3 isolated more than 130 interacting proteins with 11 proteins common in both immunoprecipitations. MIS-12 and KBP-1, two common interactors, were LAP tagged and purified isolating 11 common interactors of which 10 were found also in KNL-1 and KNL-3 immunoprecipitations. (For color version of this figure, the reader is referred to the web version of this book.) 